\title{
Review of octopamine in insect nervous systems
}

\author{
This article was published in the following Dove Press journal: \\ Open Access Insect Physiology \\ I June 2012 \\ Number of times this article has been viewed
}

\section{Tahira Farooqui \\ Department of Entomology, The Ohio State University, Columbus, $\mathrm{OH}, \mathrm{USA}$}

Correspondence: Tahira Farooqui

Department of Entomology,

The Ohio State University,

Columbus, $\mathrm{OH} 43210$, USA

$\mathrm{Tel}+\mid$ I $6 \mid 4488036$ |

Fax + I 6I4 $488036 \mid$

Email farooqui.2@osu.edu
Abstract: Octopamine (OCT) belongs to a group of compounds known as biogenic amines. OCT, a monohydroxylic analog of norepinephrine, is found in both vertebrate and invertebrate nervous systems. OCT is present in relatively high concentrations in the neuronal and nonneuronal tissues of most invertebrate species studied. However, OCT occurs as a trace amine in vertebrates where its physiological significance remains uncertain. OCT acts as a neurotransmitter, neuromodulator, and neurohormone in insect nervous systems where it prominently influences multiple physiological events. In the peripheral nervous system, OCT modulates the activity of flight muscles, peripheral organs, and most sense organs. In the central nervous system, OCT is essential for the regulation of motivation, desensitization of sensory inputs, arousal, initiation, and maintenance of various rhythmic behaviors, hygiene behavior, and complex social behaviors, including establishment of labor, as well as learning and memory. As a neurotransmitter, OCT regulates endocrine gland activity and controls the emission of light in the firefly lantern. As a neurohormone, OCT is released into hemolymph, transported to target tissues, and induces mobilization of lipids and carbohydrates, preparing insects for a period of extended activity or assisting recovery from a period of increased energy demand. OCT modulates hemocytic nodulation in nonimmune larvae and enhances phagocytosis as a neurohormone. OCT exerts its effects by binding to specific receptors belonging to the superfamily of $\mathrm{G}$ protein-coupled receptors and shares the structural motif of seven transmembrane domains. Activation of octopaminergic receptor types is coupled with different second messenger pathways depending on the species, tissue source, receptor type, and cell line used for expression of the cloned receptor. OCT-mediated generation of second messengers is associated with changes in cellular response, affecting insect behaviors. This review describes the roles of OCT in insect nervous systems at the behavioral and molecular levels.

Keywords: octopamine, octopamine receptor, biogenic amine, sympathomimetic amine, nervous systems, insects

\section{Introduction}

Octopamine (OCT) was first discovered in the salivary glands of Octopus vulgaris. ${ }^{1}$ OCT is an invertebrate structural analog of vertebrate norepinephrine. It can be distinguished from norepinephrine by the absence of a hydroxyl group at position 3 of the phenol ring (Figure 1). In invertebrates, OCT induces and modulates signal transduction pathways similar to that of norepinephrine in vertebrates. OCT is present in high concentrations in the central and peripheral nervous systems of most invertebrate species, including insects, where it plays a multifunctional role. ${ }^{2-5}$ In contrast, only trace amounts of OCT have been reported in the central and peripheral nervous 
<smiles>NC[C@@H](O)c1ccc(O)cc1</smiles><smiles>NC[C@@H](O)c1cccc(O)c1</smiles><smiles>NC[C@@H](O)c1ccccc1O</smiles>

O-OCT

$m$-OCT<smiles>NC[C@H](O)c1ccc(O)c(O)c1</smiles>

NOR<smiles>CNC[C@H](O)c1ccc(O)c(O)c1</smiles>

EPI

Figure I Chemical structures of octopamine isomers, norepinephrine, and epinephrine.

Abbreviations: $p$-OCT, para-octopamine; $m$-OCT, meta-octopamine; o-OCT, ortho-octopamine; NOR, norepinephrine; EPI, epinephrine.

systems of vertebrates. ${ }^{3-7}$ OCT is a sympathomimetic amine and known as a false neurotransmitter because it can be stored in vesicles replacing endogenous classical amines such as norepinephrine, dopamine, and serotonin. ${ }^{7}$ OCT is coreleased with other catecholamines, so many of its effects may be indirect, and the existence of octopaminergic receptors has not yet been established in vertebrates. Therefore, OCT seems to play no true physiological role in vertebrates.

OCT is found in high concentrations in the central and peripheral nervous tissues of insects where it serves as a neurotransmitter and a neuromodulator; however, when released in the hemolymph of insects it plays a neurohormonal role. ${ }^{2,4,5}$ Circulating levels of OCT are increased during "stressful" conditions, such as mobilization of lipids and sugars, so OCT is involved in adjusting an insect's body for a period of extended activity or assisting in recovery from a period of increased energy demand..$^{8-15}$ OCT produces a rapid increase in the circulating hemocyte population in response to bacterial challenge in some insects, such as the American cockroach, Periplaneta americana, and the beet armyworm, Spodoptera exigua. ${ }^{16,17}$ It is suggested that OCT mediates cellular immune responses such as hemocytic phagocytosis and nodule formation via eicosanoids during bacterial invasion in insects. As a neurotransmitter, OCT regulates emission in the light organ of the firefly and endocrine gland activity in other insects. ${ }^{18-21}$ As a peripheral neuromodulator, OCT modulates the activities of skeletal and visceral muscles, other peripheral target organs including fat body, oviduct, heart, and sensory organs, and gregarization in locusts. ${ }^{22-26}$ As a centrally acting neuromodulator, OCT plays a major neuromodulatory role in regulating insect behaviors, such as rhythmic behaviors in locusts, ${ }^{3,27}$ locomotion and grooming in fruit flies ${ }^{28}$ dance and sting behavior in honeybees, ${ }^{29,30}$ sensitization and dishabituation of sensory input in locusts, ${ }^{31,32}$ discrimination of nestmates from non-nestmates in honeybees and fire ants, ${ }^{33,34}$ feeding behaviors of blowflies, cockroaches and honeybees, ${ }^{35-37}$ division of labor and foraging preference in honeybees, ${ }^{38,39}$ conditional courtship in fruit flies, ${ }^{40}$ visual responses in locust and honeybees, ${ }^{31,41-44}$ learning and memory processes in honeybees, fruit flies, and crickets, ${ }^{45-49}$ and many others (Table 1).

Collective studies support the view that OCT orchestrates multiple physiological and behavioral processes by functioning as a neuromodulator, neurotransmitter, or neurohormone in insect nervous systems, prompting the whole organism to "dynamic action". OCT plays important roles in the insect nervous system, and the main objective of this review is to update knowledge on OCT metabolism, classification of octopaminergic neurons, octopaminergic receptors, and OCT-mediated signaling, in the hope that this review may shed light on the molecular mechanism(s) underlying complex insect behaviors. 
Table I Octopaminergic modulation of insect behaviors

\begin{tabular}{|c|c|c|}
\hline Behavior & Insect & Reference(s) \\
\hline $\begin{array}{l}\text { Olfactory learning } \\
\text { and memory }\end{array}$ & $\begin{array}{l}\text { Apis mellifera, Drosophila } \\
\text { melanogaster, and Gryllus } \\
\text { bimaculatus }\end{array}$ & $45-49$ \\
\hline $\begin{array}{l}\text { Sensitization and } \\
\text { dishabituation }\end{array}$ & Locusta migratoria & 31,32 \\
\hline Feeding response & $\begin{array}{l}\text { Phormia regina, } \\
\text { Apis mellifera, } \\
\text { Rhyparobia madera }\end{array}$ & $35-37$ \\
\hline Vision & $\begin{array}{l}\text { Locusts and } \\
\text { Apis mellifera }\end{array}$ & $31,4 \mid-44$ \\
\hline Aggression & Drosophila melanogaster & 65 \\
\hline Motor control & Locusta migratoria & $11-13$ \\
\hline Locomotion and grooming & Drosophila melanogaster & 28 \\
\hline Rhythmic behaviors & $\begin{array}{l}\text { Schistocerca gregaria } \\
\text { and Manduca sexta }\end{array}$ & 3,27 \\
\hline Division of labor & Apis mellifera & 38,39 \\
\hline Dance behavior & Apis mellifera & 29 \\
\hline $\begin{array}{l}\text { Discrimination } \\
\text { of nestmates from } \\
\text { non-nestmates }\end{array}$ & $\begin{array}{l}\text { Apis mellifera and } \\
\text { Solenopsis invicta }\end{array}$ & 33,34 \\
\hline Sting response & Apis mellifera & 30 \\
\hline Conditional courtship & Drosophila melanogaster & 40 \\
\hline $\begin{array}{l}\text { Gregarization } \\
\text { (behavioral switch) }\end{array}$ & Schistocerca gregaria & 26 \\
\hline $\begin{array}{l}\text { Activity and energy } \\
\text { metabolism of flight } \\
\text { muscles, visceral muscle, } \\
\text { peripheral organs, } \\
\text { and sense organs }\end{array}$ & $\begin{array}{l}\text { Locusta migratoria } \\
\text { and Acheta domesticus }\end{array}$ & $3,8,10-15,24$ \\
\hline Ovulation & Drosophila melanogaster & 61,64 \\
\hline
\end{tabular}

\section{Isomers}

OCT exists in three different structural isomeric forms, ie, para- $(p-)$, meta- $(m-)$, and ortho- $(o-)$, as shown in Figure 1. Each isomeric form exists as $\mathrm{D}(-)$ and $\mathrm{L}(+)$ enantiomers. ${ }^{50-53}$ However, the naturally occurring isomer of OCT is $p$-OCT in the octopus and other invertebrates, including insects, and is found in high concentration in the central nervous system, peripheral nervous system, and various other peripheral tissues. ${ }^{8,54,55}$ The (-)-enantiomer of $p$-OCT is the naturally occurring form in honeybees. ${ }^{56}$ These findings support the original findings of Harmar and Horn who showed that the $(-)$-enantiomer of $p$-OCT is over 200 times more potent than the (+)-enantiomer in stimulating adenylyl cyclase activity in the cockroach brain. ${ }^{57}$ The locust forewing stretch receptor has been reported to be more sensitive to D-OCT than to DL-OCT. ${ }^{58}$ The $p$-isomer of OCT has approximately 500 times higher affinity for OCT than does the $m$-isomer, whereas tyramine exerts a nearly eight times lower affinity than $p$-OCT for the locust neuronal OCT receptor (OCT3), suggesting that $p$-isomers and $m$-isomers of OCT have different affinities for receptors. ${ }^{59}$ Collective evidence supports the presence of $p$-OCT in insects, and the $p$-, $m$-, and $o$-isomers in mammals.

\section{Metabolism in insects Biosynthesis}

OCT biosynthesis from L-tyrosine is a two-step process in a de novo pathway (Figure 2A). In the first step, tyrosine is decarboxylated to tyramine by tyrosine decarboxylase. ${ }^{60}$ In the second step, tyramine is hydroxylated on the $\beta$-carbon of the side chain to OCT by tyramine $\beta$-hydroxylase, a rate-limiting enzyme in the biosynthetic pathway. ${ }^{61}$ The enzymatic activities of tyrosine decarboxylase and tyramine $\beta$-hydroxylase depend on the availability and concentration of substrates and cofactors. Tyrosine decarboxylase requires tyrosine and pyridoxal phosphate, whereas tyramine $\beta$-hydroxylase requires tyramine, ascorbate, and copper to catalyze the reaction. ${ }^{62}$ The enzymatic activity and stability of these enzymes may also depend on transcriptional, translational, and post-translational modifications. ${ }^{62}$

Tyrosine decarboxylase genes $(d T d c 1$ and $d T d c 2)$ and a tyramine $\beta$-hydroxylase gene $(T \beta h)$ have been cloned from Drosophila melanogaster ${ }^{61,63} d T d c 1$ is expressed non-neurally, while $d T d c 2$ is expressed neurally. Tyramine $\beta$-hydroxylase has been found in all neurons and cells that synthesize OCT. ${ }^{70}$ No detectable levels of tyramine and OCT are found in mutant $\left(T d c 2^{R O 54}\right)$ brains of $D$. melanogaster, and affected females are sterile due to egg retention but are not deficient in ovulation. ${ }^{63}$ However, mutant flies $\left(T \beta h^{n M 18}\right)$ lacking neural OCT show a 10-fold increase in tyramine levels, but the females are deficient in ovulation. ${ }^{61,64}$ These findings suggest distinct and separable neural activities of OCT and tyramine. Reduction in OCT also decreases aggression in both males and females. In genetic rescue experiments, Tdc1-Gal4-driven tyramine $\beta$-hydroxylase expression has failed to rescue the aggression phenotype of mutant male flies $\left(T \beta h^{n M 18}\right)$. However, the combination of Tdcl-Gal4 and $U A S-T \beta h$ drivers rescued the deficiency in aggression, suggesting that the aggression phenotype in $T \beta h^{n M 18}$ mutants is the result of a tyramine $\beta$-hydroxylase deficiency in the central nervous system. The combination of Tdc2-Gal4 and Cha-Gal80 to drive tyramine $\beta$-hydroxylase expression in subesophageal ganglion neurons rescued the aggression phenotype in $T \beta h^{n M 18}$ mutants, indicating that OCT and a distinct subset of octopaminergic neurons in the subesophageal ganglion have functional importance in aggression. ${ }^{65}$ Furthermore, tyramine has been reported to regulate transepithelial 
A

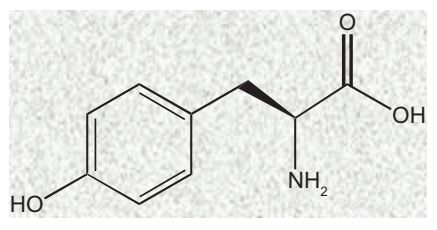

L-TYRO

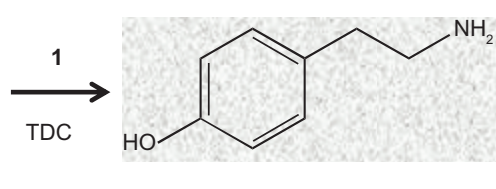

TYR

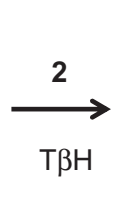

$\mathrm{HO}$

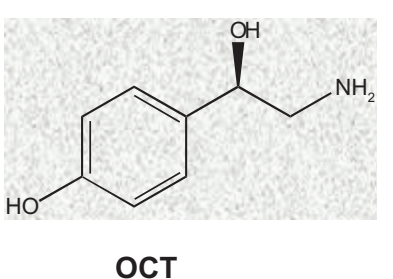

OCT

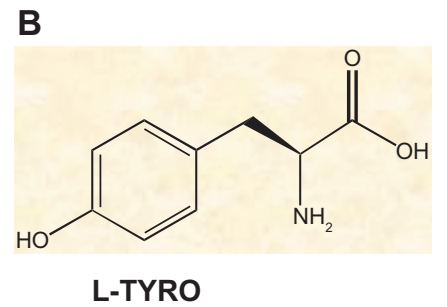

L-TYRO
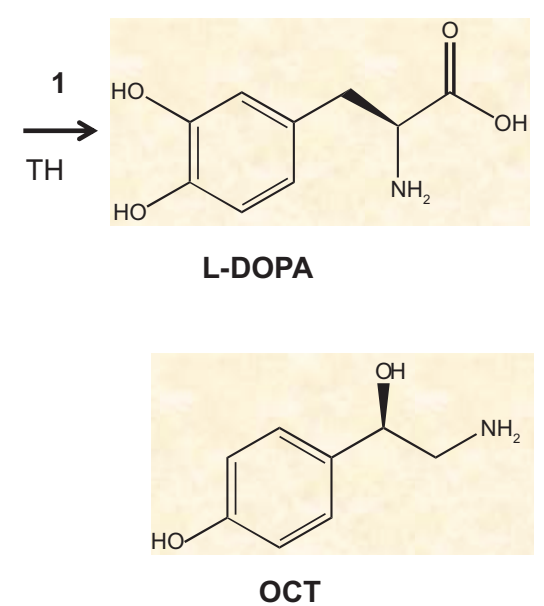

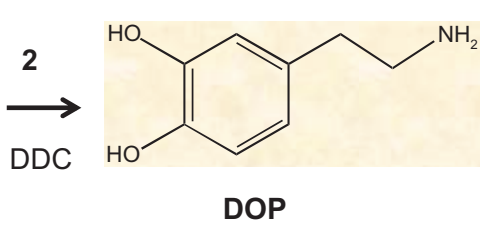

$\mathrm{DDH} \downarrow^{3}$

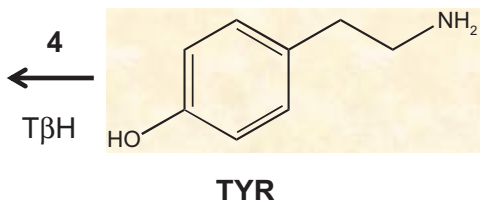

Figure 2 Biosynthetic pathways of octopamine in insects. (A) De novo pathway in which L-TYRO is decarboxylated to TYR by TDC (I). TYR is then hydroxylated to OCT by TRH (2). (B) Salvage pathway in which L-TYRO is hydroxylated to L-DOPA by TH (I). L-dopa is decarboxylated to DOP by DDC (2). DOP is then dehydroxylated to TYR by DDH (3), followed by conversion of TYR to OCT by T $\beta H$ (4).

Abbreviations: L-TYRO, L-tyrosine; TYR, tyramine; TDC, tyrosine decarboxylase; OCT, octopamine; T $\beta$ H, tyramine $\beta$-hydroxylase; L-DOPA, 3,4-dihydroxy phenylalanine; $\mathrm{TH}$, tyrosine hydroxylase; DOP, dopamine; DDC, DOPA decarboxylase; DDH, dopamine dehydroxylase.

$\mathrm{Cl}^{-}$conductance in Malpighian tubules of D. melanogaster. ${ }^{66}$ The immunohistochemical staining of Malpighian tubules with an antibody against tyramine indicates that stellate cells are the sites of tyramine production, supporting the expression of $d T d c 1$ in non-neuronal tissue..$^{63,66}$

\section{Salvage pathway}

The salvage pathway may be an alternative pathway for OCT synthesis in insects (Figure 2B). This pathway was proposed 35 years ago. ${ }^{67}$ Since then, it has been a subject of controversy on both logical and technical grounds. ${ }^{68-70}$ Later on, using improved histofluoresence technology, researchers have detected $p$-tyramine, $p$-OCT, and $p$-dopamine in the thoracic nervous system of the locust. Both octopaminergic and dopaminergic neurons have been reported to share common morphological features in the thoracic nervous system of the locust, as well as in the ventral nerve cord of the cricket. ${ }^{71,72}$ Theoretically, in the salvage pathway, the tyrosine decarboxylase reaction may be replaced by tyrosine hydroxylase that converts L-tyrosine to 3,4-dihydroxy-phenylalanine (L-dopa) via a hydroxylation reaction. ${ }^{73} \mathrm{~L}$-dopa is then decarboxylated to dopamine by dopamine decarboxylase. ${ }^{74}$ Dopamine may then be subsequently converted to tyramine by dopamine dehydroxylase, ${ }^{75}$ followed by $\beta$-hydroxylation of tyramine to form OCT.

Hydroxylation of L-tyrosine to L-dopa followed by its decarboxylation to dopamine has been reported in the cerebral ganglion of the cockroach, P. americana $\mathrm{L} .{ }^{73}$ The presence of additional L-dopa results in increased OCT synthesis. ${ }^{76,77}$ These studies suggest that OCT and dopamine synthesis share a common first step in the hydroxylation of L-tyrosine to L-dopa in the salvage pathway (Figure 2B). The physiological relevance of this salvage pathway in insects is still not fully understood. However, it may promote the availability of tyramine during diminished levels of tyrosine decarboxylase at certain sites or stages of development in the central and/or peripheral nervous systems of insects.

\section{Release, reuptake, and enzymatic inactivation}

In insects, OCT is released into the extracellular space through exocytosis to modulate various metabolic activities. Using labeled OCT, it has been shown that OCT is released by depolarization through high potassium concentration or electrical stimulation. ${ }^{78-82}$ Once OCT is released into the 
extracellular space, it binds to its postsynaptic receptors to elicit a physiological response. However, OCT release in the cytosol and reuptake is regulated by the presence of two types of transporters, ie, the transporter that carries OCT into secretory vesicles for storage by endocytosis and the transporter that mediates the reuptake of OCT following exocytosis. Both types of transporters play important roles, not only in the regulation of OCT homeostasis, but also in octopaminergic neurotransmission.

OCT is cleared rapidly from the extracellular space via a reuptake system involving membrane-bound transporters. ${ }^{83-86}$ Reverse-transcription polymerase chain reaction studies indicate that the OCT-type monoamine transporter is widely expressed in all insects, except in representatives of either Diptera (eg, D. melanogaster) or Hymenoptera (eg, Apis mellifera). ${ }^{86}$ D. melanogaster utilizes less selective transporters for cationic amino acids or organic cations as an alternative mechanism for OCT transport. ${ }^{87,88}$ The OCT reuptake system in cockroaches and other insects is strongly inhibited by cocaine, an alkaloid isolated from coca plant (Erythroxylum coca) leaves. Cocaine exerts its insecticidal effect at naturally occurring concentrations in coca leaves by blocking OCT reuptake at octopaminergic end terminals in the insect brain, which results in increased OCT concentration in the synaptic cleft, leading to the potentiation of OCT-mediated responses. ${ }^{89}$ The common occurrence of a phenolamine transporter amongst insects but lack of such a transporter in D. melanogaster and $A$. mellifera suggests species-specific existence of OCT reuptake systems, implying that OCT may be recycled at the synaptic cleft by alternative pathways. Further genetic and protein-based studies are required to understand the underlying role of transporters in the regulation of OCT release and reuptake systems in insects, because reuptake systems are considered to be an important target for synthesizing specific uptake inhibitors, which can act as novel insecticides.

Enzymatic inactivation of OCT in insects occurs due to amino terminal tagging of selective groups in its structure, and is catalyzed by specific enzymes (Figure 3 ). The main pathway of OCT inactivation in the central nervous system of the insect is via $\mathrm{N}$-acetylation. This reaction is catalyzed by a cytoplasmic $N$-acetyltransferase, which acetylates the amino moiety of OCT, thereby converting it into $\mathrm{N}$-acetylOCT, downplaying the mechanism of inactivation of oxidative deamination. ${ }^{3,67,90-94}$ Measurable $N$-acetyltransferase activity has been reported in the ventral nerve cord of the cockroach, the central nervous system of the tobacco hornworm and fruit fly, the firefly light organ, and the larvae of the cattle tick. ${ }^{95-97}$ Some insects also utilize phenylethanolamine $N$-methyl transferase to convert OCT into synephrine via an $N$-methylation reaction. ${ }^{3,98}$

Other possible pathways for enzymatic inactivation of OCT may be conjugation reactions, such as $\beta$-alanine conjugation, $\gamma$-glutamylation, and sulfate conjugation (Figure 3). ${ }^{3,94,96}$ The $\beta$-alanine conjugation reaction is catalyzed by ebony protein in $D$. melanogaster. ${ }^{99}$ The presence of $N$ - $\beta$-alanyl tyramine has been reported in the central nervous system of Manduca sexta, and $N$ - $\beta$-alanyl-OCT as well as sulfated conjugates of OCT, dopamine, and serotonin in lobster neurons. ${ }^{99}$ The ebony gene cloned from the $P$. americana brain shows homology with ebony sequences from Anopheles gambiae, $A$. mellifera, and $D$. melanogaster. ${ }^{100}$ These studies support the occurrence of alanine conjugation as an alternative pathway for biogenic amine inactivation in the central nervous system of invertebrates, including insects. The $\gamma$-glutamylation is catalyzed by $\gamma$-glutamyltransferase. . $^{3,94,100}$ This pathway has been observed in the horseshoe crab Limulus brain and eyes where $\gamma$-glutamyl OCT plays a role as an intracellular transmitter in the Limulus visual system. ${ }^{101}$ OCT inactivation via sulfation catalyzed by $O$-sulfotransferase has been reported in lobsters. ${ }^{102} \mathrm{O}$-sulfo- $\mathrm{N}$-glutamyl OCT may either be synthesized directly via sulfation of $N$-glutamyl-OCT, a reaction catalyzed by an aryl sulfotransferase; or through a reaction catalyzed by $\gamma$-glutamyltransferase using OCT- $O$ sulfate as a substrate, a reaction previously suggested for serotonin catabolism in the mollusc, Aplysia californica. ${ }^{103,104}$ Based on these findings, it is suggested that $\beta$-alanine, glutamate, and sulfate conjugation reactions may be other major pathways for inactivation of biogenic amines in the insect nervous system (Figure 3). Lastly, monoamine oxidase (the key enzyme in the monoamine inactivation pathway in vertebrates) plays a minor role in inactivating OCT in the insect nervous system. ${ }^{93}$

\section{Octopaminergic neurons in the insect nervous system}

The number of octopaminergic neurons in the insect nervous system varies considerably. The approximate number of neurons present in all ganglia of large insects is 108 , and in small insects approximately $40-50$ neurons. The distribution of octopaminergic neurons is well documented in insects including honeybees, fruit flies, blowflies, cockroaches, hawkmoths, and locusts. ${ }^{105-112}$ The best characterized group of neuromodulatory neurons in insects constitutes a unique group of unpaired efferent median neurons, the somata of which are located at the dorsal/ventral midline of the 


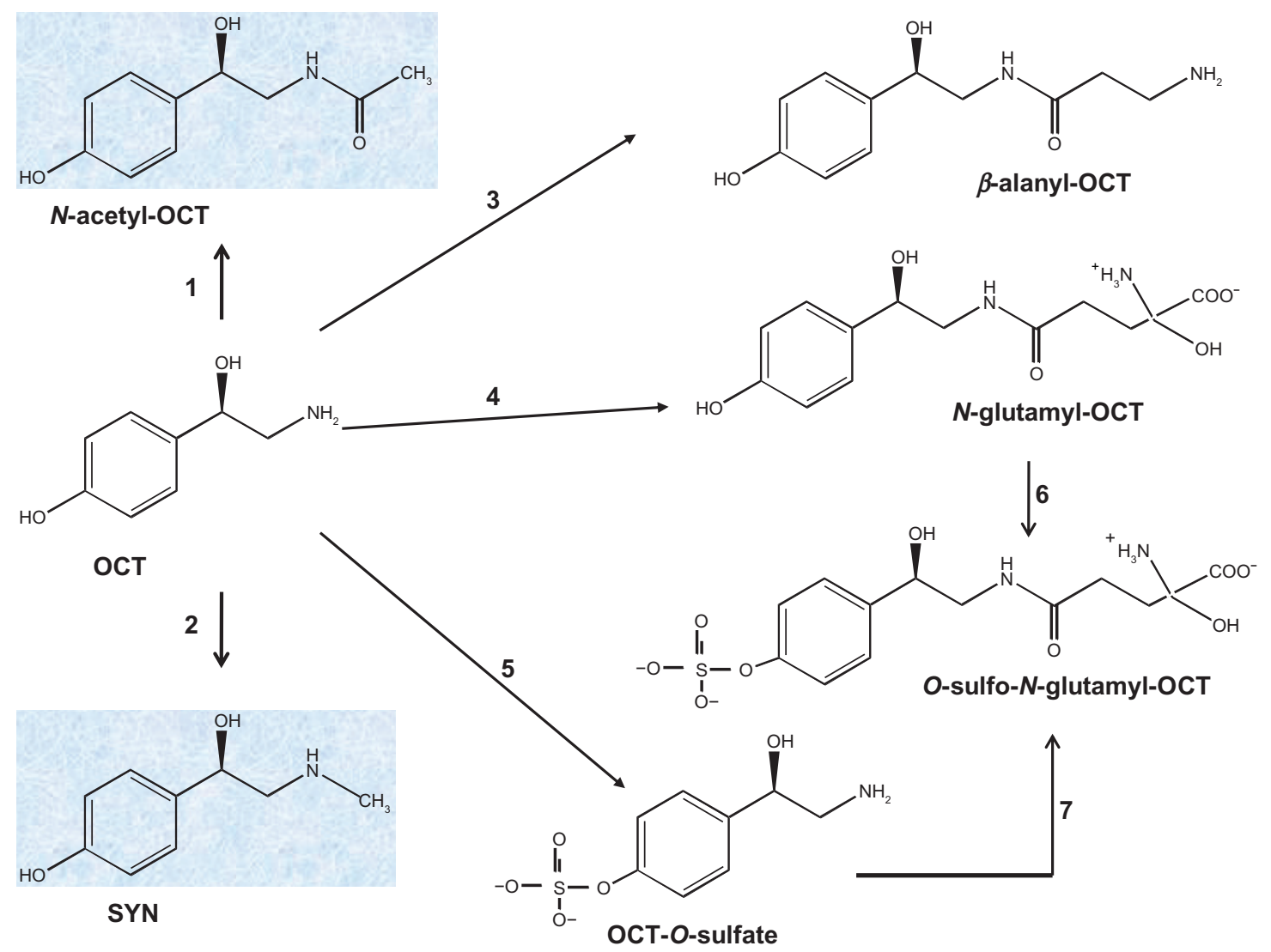

Figure 3 Enzymatic inactivation of octopamine in insects.

Notes: Enzymes involved in OCT degradative reactions are $\mathrm{N}$-acetyltransferase (I), PNMT (2), ebony (3), $\gamma$-glutamyltransferase (4), $\mathrm{O}$-sulfotransferase (5), aryl sulfotransferase (6), and $\gamma$-glutamyltransferase (7). Conversion of OCT to $\mathrm{N}$-acetyl-OCT by $\mathrm{N}$-acetylation is a major enzymatic pathway, whereas conversion of OCT to SYN has limited importance in inactivating OCT.

Abbreviations: PNMT, phenylethanolamine N-methyl transferase; OCT, octopamine; SYN, synephrine.

subesophageal ganglion, thoracic, and abdominal ganglia; these neurons are known as dorsal unpaired median or ventral unpaired median neurons. ${ }^{113-116}$ The classification of OCTlike immunoreactive neurons as clusters of cell bodies and perikarya within the cell body in the brain and the subesophageal ganglion has been reviewed elsewhere. ${ }^{106,107,111,117}$ Most unpaired dorsal/ventral efferent median neurons are octopaminergic..$^{24,108,109} \mathrm{~A}$ subpopulation of the subesophageal ganglion dorsal/ventral unpaired median cells innervates most parts of the brain neuropils and is involved with specific activities and complex behaviors. ${ }^{105,118}$ The dorsal unpaired median and ventral unpaired median neurons also innervate sets of peripheral muscles, glands, and certain types of proprioceptors. ${ }^{119}$ The peripherally released OCT from dorsal/ ventral unpaired median neurons modulates neuromuscular transmission, muscle contraction kinetics, muscle metabolism, and sensory sensitivity, and influences other properties of target organs. However, when released into the circulation, hemolymph OCT acts as a lipid mobilizing neurohormone during flight and long-lasting motor behaviors. ${ }^{8,119-121}$
Recent immunocytochemical studies clearly demonstrate a fine and comparable distribution of octopaminergic neurons using antibody raised against OCT. ${ }^{106-108,111}$ Several well distinguished clusters of lateral cell bodies in the brain and many midline perikarya provide OCT-like immunoreactive processes to circumscribed regions of the subesophageal ganglion, antennal lobes, optic lobes, and protocerebrum neuropils in different insect species. The locations and projection patterns of OCT-immunoreactive neurons in the brain neuropils and subesophageal ganglion of different insects tested suggest some overlap with distinct differences in the distribution of OCT-immunoreactive processes, implicating common as well as highly specific targets among insect species. ${ }^{107}$ Further evaluation will be helpful in recognizing additional neuromodulatory elements because some midline neurons show no OCT-like immunoreactivity on their dendritic processes but possess immunoreactive cell bodies. A previously reported overlap between the distribution of OCT-immunoreactive processes and expression of octopaminergic receptors in insect brain neuropils and in the 
subesophageal ganglion ${ }^{111}$ needs further confirmation by evaluating this overlap among various other insect species.

The modulatory roles of OCT-like neurons do not depend solely on their origin but also on the arborization patterns in the target organs where they release OCT. Several groups have investigated the sites of OCT release in the central and peripheral nervous systems and the origin, arborization, and modulatory roles of OCT neurons..$^{94,105-124}$ It is timely to determine OCT levels, octopaminergic receptor subtype/density, and neural activity/connectivity in specific brain neuropils to show the correlation with complex behaviors in insects.

\section{Receptor classification}

The original octopaminergic receptor classification was based on the pharmacological profiles of a range of physiological responses to OCT in an extensor tibiae muscle preparation of the locust. ${ }^{125}$ According to this classification (Figure 4A), octopaminergic receptors in the insect were functionally

A

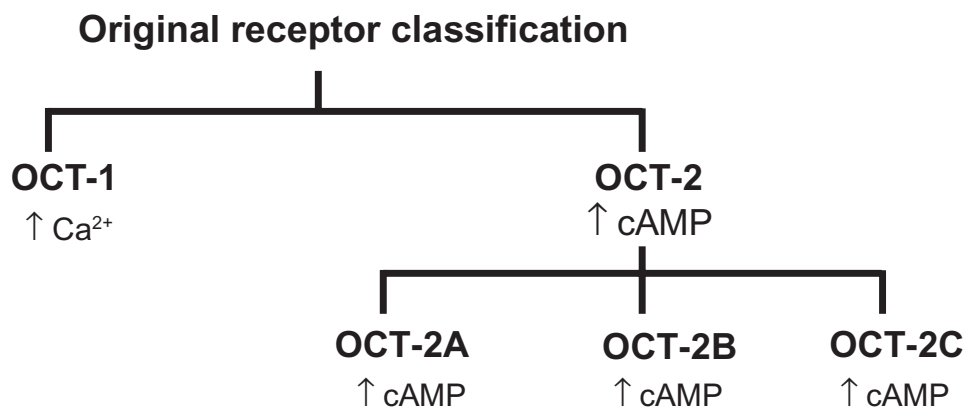

B New receptor classification

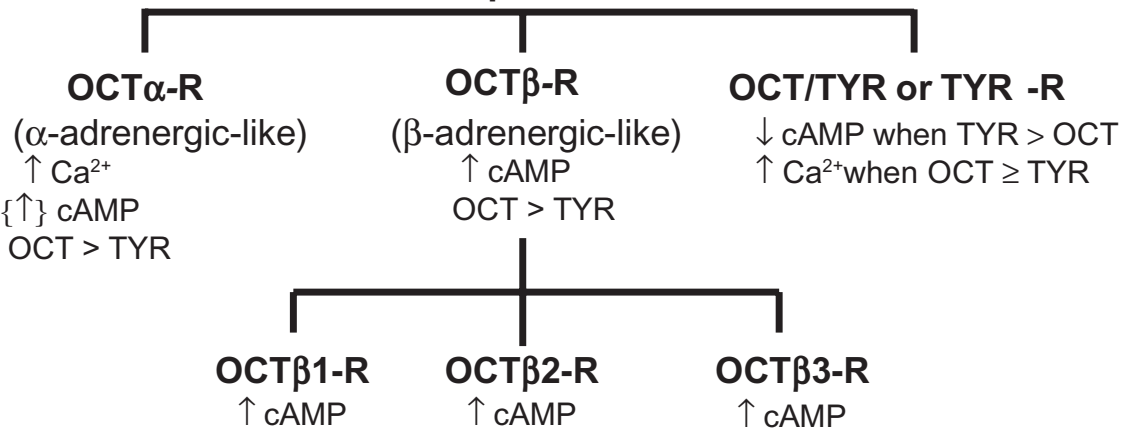

C

Revised new receptor classification

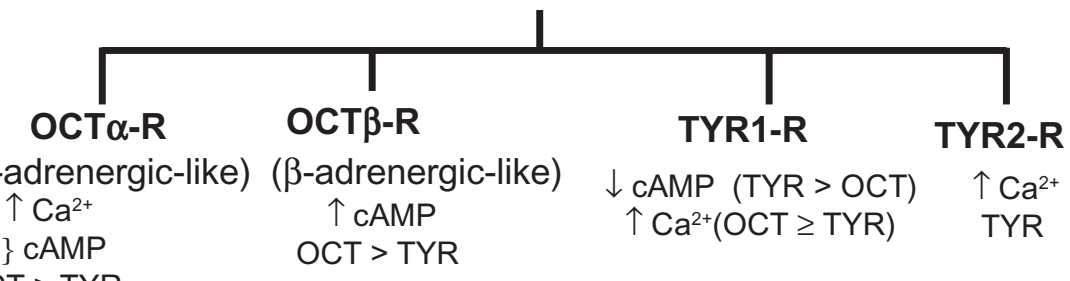

OCT > TYR

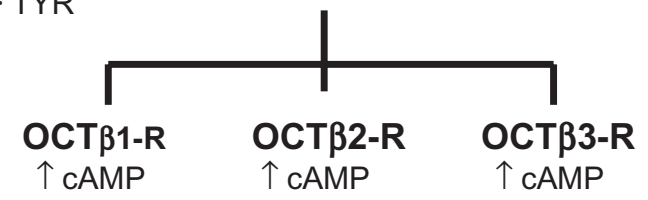

Figure 4 Classification schemes of octopaminergic receptors. (A) Original scheme receptor classification based on whole tissue responses, (B) new receptor classification based on the structural and signaling similarities of fruit fly cloned Drosophila melanogaster octopaminergic receptors with vertebrate adrenergic receptors, and (C) revised new receptor classification based on cloning and functional studies of second class of tyraminergic receptors. Information is adapted from previous references. ${ }^{17,125,149-151}$ Abbreviations: Ca2+, calcium; cAMP, cyclic adenosine monophosphate; $\uparrow$, increase; $\downarrow$, decrease. OCT, octopamine; TYR, tyramine. 
classified into two main classes, ie, OCT-1 and OCT-2. ${ }^{125}$ The OCT-1 class of receptors is associated with an increase in intracellular calcium $\mathrm{Ca}^{2+}$ levels, whereas the OCT-2 class of receptors is associated with an increase in intracellular cAMP levels. ${ }^{117,125-127}$ Based on this pharmacological difference, the OCT-2 class of receptors was initially divided into two subclasses (A and $\mathrm{B}$ ). OCT-2A receptors are located on the presynaptic terminals of the slow motor neuron and modulate transmitter release, whereas OCT-2B receptors are located postsynaptically on the muscle and modulate the relaxation rate of twitch tension. ${ }^{125}$ Subsequently, a third class, OCT-3, was pharmacologically characterized in the locust brain. OCT-3 is different from the peripheral octopaminergic receptors $(1,2 \mathrm{~A}$, and $2 \mathrm{~B})$ in terms of its rank order of affinities for selected antagonists and distribution in the insect brain. ${ }^{94,129,130}$ OCT-3 is referred to as OCT-2C due to similarities with OCT-2A and OCT-2B in coupling, with increased intracellular cAMP levels. This classification is based on second messenger changes induced in a variety of intact tissue preparations, so is considered to be problematic, particularly given the existence of more than one receptor subtype in the same tissue preparation.

Later on, progress in molecular cloning studies eased the identification of genes coding for octopaminergic and tyraminergic receptors in insects. ${ }^{26,131-148}$ Based on the structural and signaling similarities between cloned D. melanogaster octopaminergic receptors and vertebrate adrenergic receptors, Evans and Maqueira proposed a new classification. ${ }^{149}$ According to this new classification (Figure 4B), octopaminergic receptors were grouped into three classes, ie, $\alpha$-adrenergic-like (OCT $\alpha$-R), $\beta$-adrenergic-like (OCT $\beta$-R), and octopaminergic/tyraminergic (OCT/TYR-R) or tyraminergic (TYR-R). ${ }^{149}$ The OCT $\alpha$-R class shows sequence homology with vertebrate $\alpha 1$-adrenergic receptors. These receptors exert a higher affinity for OCT than tyramine and are coupled with an increase in intracellular $\mathrm{Ca}^{2+}$ concentration as well as a small increase in intracellular cAMP levels. ${ }^{137,138,141,143,145}$ The OCT $\beta$-R class shows sequence similarities with vertebrate $\beta$-adrenergic receptors, and activation of receptors in response to OCT specifically results in increased intracellular cAMP levels. ${ }^{144,149}$ The OCT $\beta$ - $\mathrm{R}$ class is subdivided into several subclasses, which are pharmacologically different from each other. ${ }^{144}$

The OCT/TYR-R or TYR-R class of receptors has structural and pharmacological similarities with vertebrate $\alpha 2$-adrenergic receptors. ${ }^{149}$ Depending on the preference of the agonist, these receptors can be stimulated by both tyramine and OCT. The activation of OCT/TYR-R or TYR-R in response to tyramine is coupled with inhibitory $G$ protein that inhibits adenylyl cyclase, reducing intracellular cAMP levels. ${ }^{132,133,139,140,148}$ However, receptor activation in response to OCT is coupled with an increase in intracellular $\mathrm{Ca}^{2+}$ release. ${ }^{135,136}$ Later on, Cazzamali et al cloned a gene (CG7431) from D. melanogaster and expressed it in Chinese hamster ovary cells or Xenopus oocytes. ${ }^{150}$ This group reported that the expressed receptor encodes a protein that is specifically activated by tyramine, implying that it may belong to a new family of tyraminergic receptors. ${ }^{150}$ In addition to CG7431, this group identified three more homologous genes (one from D. melanogaster (CG16766), and two tyramine-like receptor genes in the genomic databases (from the mosquito $A$. gambiae and the honeybee $A$. mellifera), and reported that all four tyramine-like receptors are phylogenetically distinct from the previously identified insect OCT/TYR-R or TYR-R class of receptors. ${ }^{150}$

Huang et al cloned a cDNA from the nerve tissue of the Bombyx mori silk worm and expressed it in HEK-293 cells. ${ }^{151}$ This gene encodes a receptor protein (BmTAR2), which has considerably higher affinity for tyramine than other biogenic amines. BmTAR2 shows a tyramine-induced dose-dependent increase in intracellular $\mathrm{Ca}^{2+}$ levels $\left(\mathrm{EC}_{50} 11.6 \mathrm{nM}\right)$, whereas OCT and dopamine increase intracellular $\mathrm{Ca}^{2+}$ levels only at high concentrations $(>100 \mathrm{mM})$. The selective coupling to intracellular $\mathrm{Ca}^{2+}$ mobilization but no effect on intracellular cAMP concentration suggests that BmTAR2 may also belong to a new family of tyraminergic receptors. ${ }^{151}$ These findings favor a revision in the new receptor classification of Evans and Maqueira (Figure 4B), ${ }^{149}$ by adding another subclass in the tyraminergic class of receptors as shown in Figure 4C. ${ }^{150,151}$

Furthermore, the author has created a phylogenetic tree based on the comparison of 25 complete nucleotide sequences of insect octopaminergic and tyraminergic receptor genes by using the "Muscle" sequence alignment program. ${ }^{153-155}$ Based on nucleotide sequence homology in the phylogenetic tree, insect octopaminergic receptor sequences from the moth $M$. sexta $(\mathrm{MsOA}),{ }^{146}$ D. melanogaster $(\mathrm{OAMB}){ }^{137}$ and splice variants (DmOA1A, and DmOA1B), ${ }^{143}$ A. mellifera (AmOA1), ${ }^{138}$ P. americana (PaOA1), ${ }^{142}$ B. mori (BmOAR1), ${ }^{145}$ and locust Schistocerca gregaria $(\mathrm{SgOct} \alpha \mathrm{R})^{26}$ cluster together in the Oct $\alpha-\mathrm{R}$ class, whereas $S$. gregaria $(\mathrm{SgOct} \beta \mathrm{R}),{ }^{26} \mathrm{~B}$. mori (BmOAR2), ${ }^{152}$ and D. melanogaster (DmOct $\beta 1-\mathrm{R}$, DmOct $\beta 2-\mathrm{R}$, DmOct $\beta 3-\mathrm{R})^{144}$ fall into the Oct $\beta-\mathrm{R}$ class (Figure 5). Tyraminergic receptor sequences from $A$. mellifera (Amtyr1), ${ }^{148}$ B. mori (BmTAR1), ${ }^{140}$ Heliothis virescens 


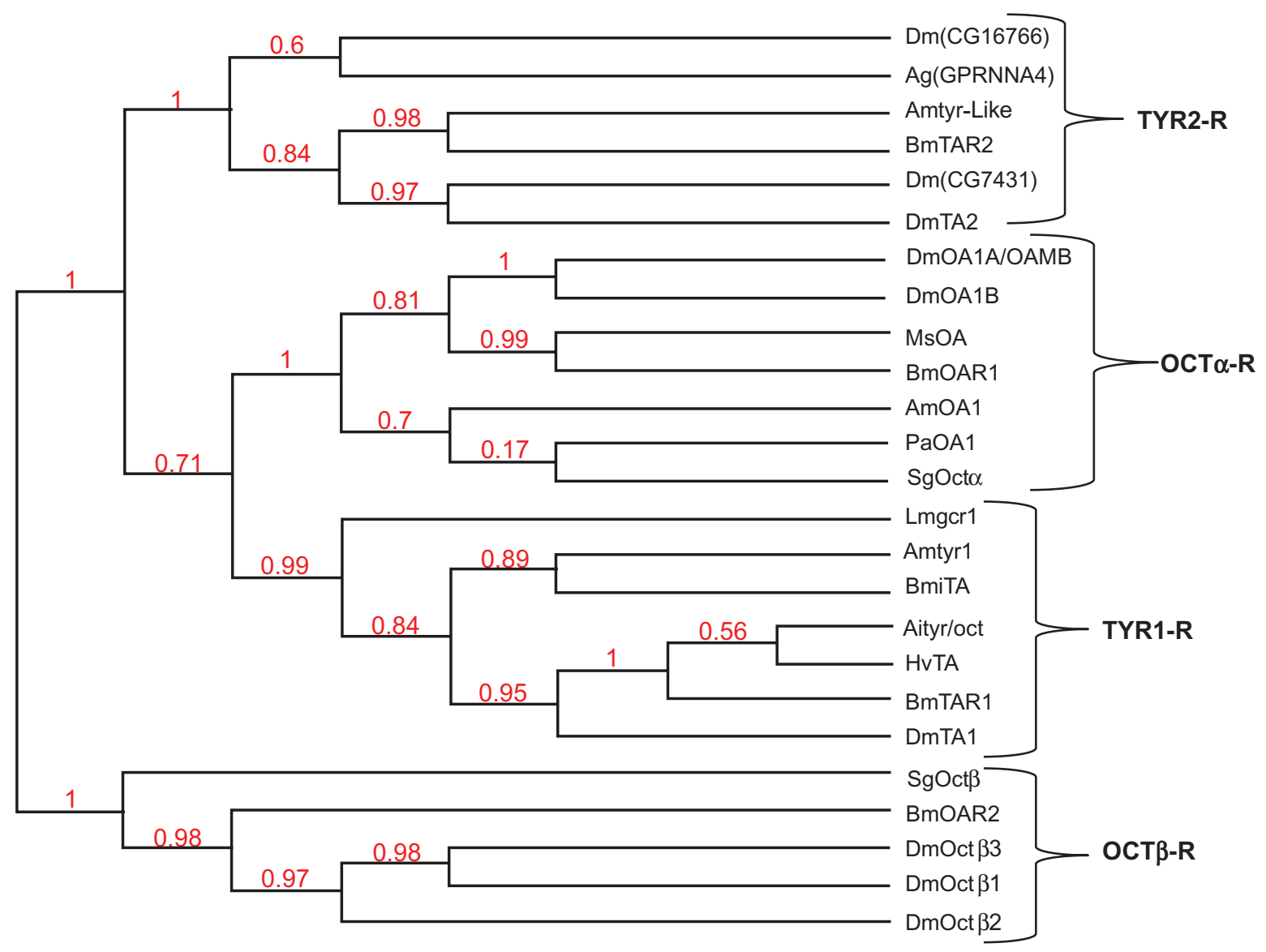

Figure 5 Phylogenetic tree comparison of insect octopaminergic and tyraminergic receptors with respect to the new classification proposed by Evans and Maqueira. ${ }^{149}$ Notes: Nucleotide sequences were aligned with Muscle (v3.7). After alignment, ambiguous regions containing gaps and/or poorly aligned were removed. The phylogenetic tree was constructed using the maximum likelihood method implemented in the PhyML program. The model (HKY85, statistical test aLRT) was used assuming an estimated proportion of invariant sites (of 0.057 ) and four gamma-distributed rate categories to account for rate heterogeneity across sites. The gamma shape parameter was estimated directly from the data (gamma 0.789), and the reliability for the internal branch was assessed using the aLRT test. ${ }^{153-155} \mathrm{NCBI}$ Databank accession number of genes sequences: AmOAI, AJ547798; DmOAMB, AF065443; DmOAIA, AJ0076I8; DmOAIB, AJ0076I7; PaOAI, AY333 I78; BmOARI, AB255I63; MsOA, DQ8405I4; SgOcto,

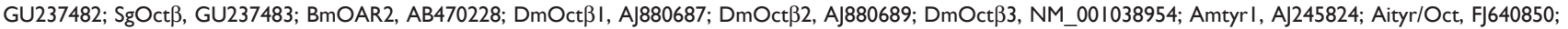
BmiTA, AJ0I0743; HvTA, X95606; Lmtyr (gcrl), X69520; BmTARI, NM_001044039; DmTAI (Tyr-Dro), X54794; DmTA2, AY034I7; BmTAR2, AB46248I; Dm(CG743I), NM_142395; Dm(CGI6766), NM_142394; Amtyr-like, NM_0010373I8; and the genome of the malaria mosquito Ag(GPRNNA4), XM_309588).

Abbreviations: Am, Apis mellifera; Dm, Drosophila melanogaster; Pa, Periplaneta americana; Ms, Manduca sexta; Sg, Schistocerca gregaria; Bm, Bombyx mori; Hv, Heliothis virescens; Ai, Agrotis ipsilon; Bm, Bophilus microplus; Lm, Locusta migratoria; Ag, Anopheles gambiae; NCBI, National Center for Biotechnology Information; OCT, octopamine; TYR, tyramine.

(HvTA), ${ }^{134}$ Agrotis ipsilon (Aityr/OCT), ${ }^{141}$ Locusta migratoria (Lmtyr1), ${ }^{139}$ and the cattle tick Boophilus microplus (BmiTA) $)^{147}$ fall into the Tyr1-R subclass. However, B. mori (BmTAR2), ${ }^{151}$ D. melanogaster (DmTA1 or Tyr-Dro), ${ }^{132} D$. melanogaster (DmTA2, DmCG7431, DmCG16766), ${ }^{150} A$. mellifera (Amtyr-ike), ${ }^{150}$ and $A$. gambiae genome sequences (GPRNNA4) ${ }^{150}$ cluster together in the TYR2-R subclass (Figure 5). This phylogenetic tree further supports applicability of the new Evans and Maqueira classification scheme, except that there are two subclasses in the tyraminergic receptor class.

Collectively, based on information obtained from pharmacological and functional studies of expressed receptor proteins and phylogenetic tree analysis of nucleotide sequences, it is logical to accept revision of the new receptor classification by including an additional subclass in the tyraminergic class of insect receptors.

\section{Structural and function of octopaminergic and tyraminergic receptors}

Similar to adrenergic receptors in mammals, insect octopaminergic and tyraminergic receptors belong to the superfamily of $\mathrm{G}$ protein-coupled receptors, which share a structural motif of seven transmembrane domains (TM 1-7) to mediate signal transduction in response to an agonist. ${ }^{156-160}$ The N-terminus $\left(\mathrm{NH}_{2}\right)$ of biogenic amine receptors is located 
extracellularly and the C-terminus $(\mathrm{COOH})$ intracellularly. The N-terminal domain often contains several consensus sites for N-linked glycosylation. ${ }^{156,161}$ The TM 1-7 in G protein-coupled receptors is linked by three extracellular loops (EL-1 to EL-3) and three intracellular (IL-1 to IL-3) loops. The signature residues, such as an aspartate (D) residue in TM3, serine (S) residues in TM5, and a phenylalanine $(\mathrm{F})$ residue in TM6, are conserved in all biogenic amine receptors and contribute to ligand binding. ${ }^{156-160}$ The $\alpha$-adrenergic-like OCT $\alpha$-R class of receptors is coupled to both $\mathrm{G}_{\mathrm{s}}$ and $\mathrm{G}_{\mathrm{q}}$ proteins, inducing release of the intracellular second messengers, cAMP and $\mathrm{Ca}^{2+}$. A point mutation study performed in BmOAR1, the $\alpha$-adrenergic-like OCT receptor, has reported that residues such as D103 in TM3, S198 in TM5, and tyrosine (Y) in TM6 are involved in OCT binding and activation of this receptor through electrostatic or hydrogen bond interactions, but S202 does not participate in this process. ${ }^{162}$ The wild-type BmOAR1 exhibits significant stereoselectivity for OCT enantiomers in cAMP production and binding affinity, but not in the $\mathrm{Ca}^{2+}$ signaling response. ${ }^{163}$ However, Y to F mutation (Y412F) in BmOAR1 abolishes discrimination between OCT enantiomers in binding affinity and does not evoke any cAMP signaling response, suggesting that Y412 may act as a molecular switch to regulate distinct $\mathrm{G}$ protein or multiple $\mathrm{G}$ protein couplings. ${ }^{163}$

Other amino acids that maintain the structure and function of $\mathrm{G}$ protein-coupled receptors include: a chain of aspartate, arginine, and tyrosine at the cytoplasmic interface of TM3, which is involved in receptor coupling to G protein; two cysteines, one in EL-1 and the other in EL-2, which are involved in forming the disulfide bridge that stabilizes the receptor; and 1-3 cysteine (C) residues in the cytoplasmic tail which may be involved in post-translational modification of receptors with long-chain fatty acids. ${ }^{158,160,164}$ The insertion of palmitic acid (a 16C saturated fatty acid) occurs at one or more cysteine residues on the intracellular side of $\mathrm{G}$ proteincoupled receptors in the plasma membrane through a thioester linkage, and this post-translational modification is known as protein palmitoylation. ${ }^{165}$ The thioester bond formed between the palmitate and the cysteine is cleavable, so the palmitoylation state of a receptor can be used to regulate its activity. ${ }^{166}$ It has been reported that, in rare cases, other lipids can also be attached to $\mathrm{G}$ protein-coupled receptors, allowing palmitoylation to occur on residues other than cysteine. ${ }^{167}$ It is likely that, similar to many G protein-coupled receptors, most insect octopaminergic and tyraminergic receptors may undergo palmitoylation, but the enzymatic mechanism involved in palmitoylation remains elusive.
The conserved serine residues in TM5 of adrenergic receptors are believed to interact with the hydroxyl groups of the catecholamine ring to produce hydrogen bonding. ${ }^{168,169}$ These residues are separated by intervening amino acid residues. ${ }^{170} \mathrm{~A}$ multiple sequence alignment of insect octopaminergic and tyraminergic receptor sequences produced by ClustalW (2.0.12) $)^{171}$ shows that the conserved serine residues in TM5 are separated by a chain of alanine, leucine, and glycine in the Oct $\alpha-R$ class. Similar to the OCT $\alpha-R$ class, separation is achieved by three intervening amino acid residues in the TYR2-R class but the leucine residue in the alanineleucine-glycine chain is replaced with methionine (Figure 6). In contrast, two serine residues are separated by either one or two intervening amino acids in the OCT $\beta$-R and TYR1-R classes (Figure 6). Such differences in the amino acid chain and in the number of intervening residues may depend on the variation in agonist binding affinity with different receptor subtypes due to coupling capacities with second messenger systems via different $G$ proteins $\left(G_{s}, G_{i}\right.$, and $\left.G_{q}\right)$ involving different signaling enzymes such as adenylyl cyclase, protein kinase C, and phospholipase C. ${ }^{160,170}$

\section{Octopamine and tyramine- mediated signaling}

Similar to other biogenic amines, octopamine and tyramine signaling is mediated through binding to distinct receptors that belong to a family of metabotropic $\mathrm{G}$ protein-coupled receptors (Figure 7). The second messengers include $\mathrm{Ca}^{2+}$, cAMP, inositol-1,4,5-trisphosphate, and diacylglycerol, depending on species, tissue source, receptor type, and cell line used for the expression of cloned receptor. ${ }^{117,160}$ The interaction of octopamine with OCT $\alpha$ class of receptors (OCT $\alpha-\mathrm{R}$ ) is coupled with an increase in intracellular $\mathrm{Ca}^{2+}$ levels as well as a relatively small increase in levels of intracellular cAMP in response to octopamine (Figure 7). ${ }^{17,137,138,142,143}$ The ligand binding to Oct $\alpha-\mathrm{R}$ class is coupled with activation of phospholipase $\mathrm{C}$ via the $\mathrm{G}_{\mathrm{q}}$ family of $\mathrm{G}$ proteins. ${ }^{117,137}$ Phospholipase $\mathrm{C}$ enzyme hydrolyzes phosphatidylinositol 4,5-bisphosphate into inositol 1,4,5-trisphosphate and diacylglycerol. Inositol 1,4,5-trisphosphate binding to its receptor in the endoplasmic reticulum results in the opening of $\mathrm{Ca}^{2+}$ channels, allowing $\mathrm{Ca}^{2+}$ release into the cytoplasm. Diacylglycerol and $\mathrm{Ca}^{2+}$ activate protein kinase $\mathrm{C}$ which regulates the physiological response by phosphorylating various signaling proteins and ion channels. However, the activation of Oct $\alpha-R$ by octopamine stimulates adenylyl cyclase via the stimulatory $G$ proteins $\left(G_{s}\right)$, inducing the production of intracellular cAMP levels, in turn stimulating 


\begin{tabular}{|c|c|}
\hline \multirow{5}{*}{$\frac{\mathscr{1}}{\frac{1}{0}} \frac{1}{0}$} & \\
\hline & SgOct $\alpha$ \\
\hline & $\mathrm{MsOA}$ \\
\hline & AmoA1 \\
\hline & DmOA1A/OAMB \\
\hline \multirow{6}{*}{$\frac{\stackrel{\sim}{\sim}}{\underset{N}{\alpha}}$} & DmOA1B \\
\hline & BmOAR1 \\
\hline & DmTA2 \\
\hline & $\mathrm{Dm}(\mathrm{CG} 7431)$ \\
\hline & BmTAR2 \\
\hline & Ag(GPRNNA4) \\
\hline \multirow{8}{*}{$\frac{\frac{\alpha}{1}}{\frac{1}{\alpha}}$} & Amtyr-like \\
\hline & Dm(CG16766) \\
\hline & BmTAR1 \\
\hline & Aityr/oct \\
\hline & HvTA \\
\hline & Amtyr1 \\
\hline & Lmtyr \\
\hline & DmTA1 \\
\hline \multirow{6}{*}{ 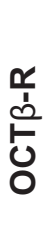 } & BmiTA \\
\hline & SgOct $\beta$ \\
\hline & DmOct $\beta 2$ \\
\hline & BmOAR2 \\
\hline & DmOct $\beta 1$ \\
\hline & DmOct $\beta 3$ \\
\hline
\end{tabular}

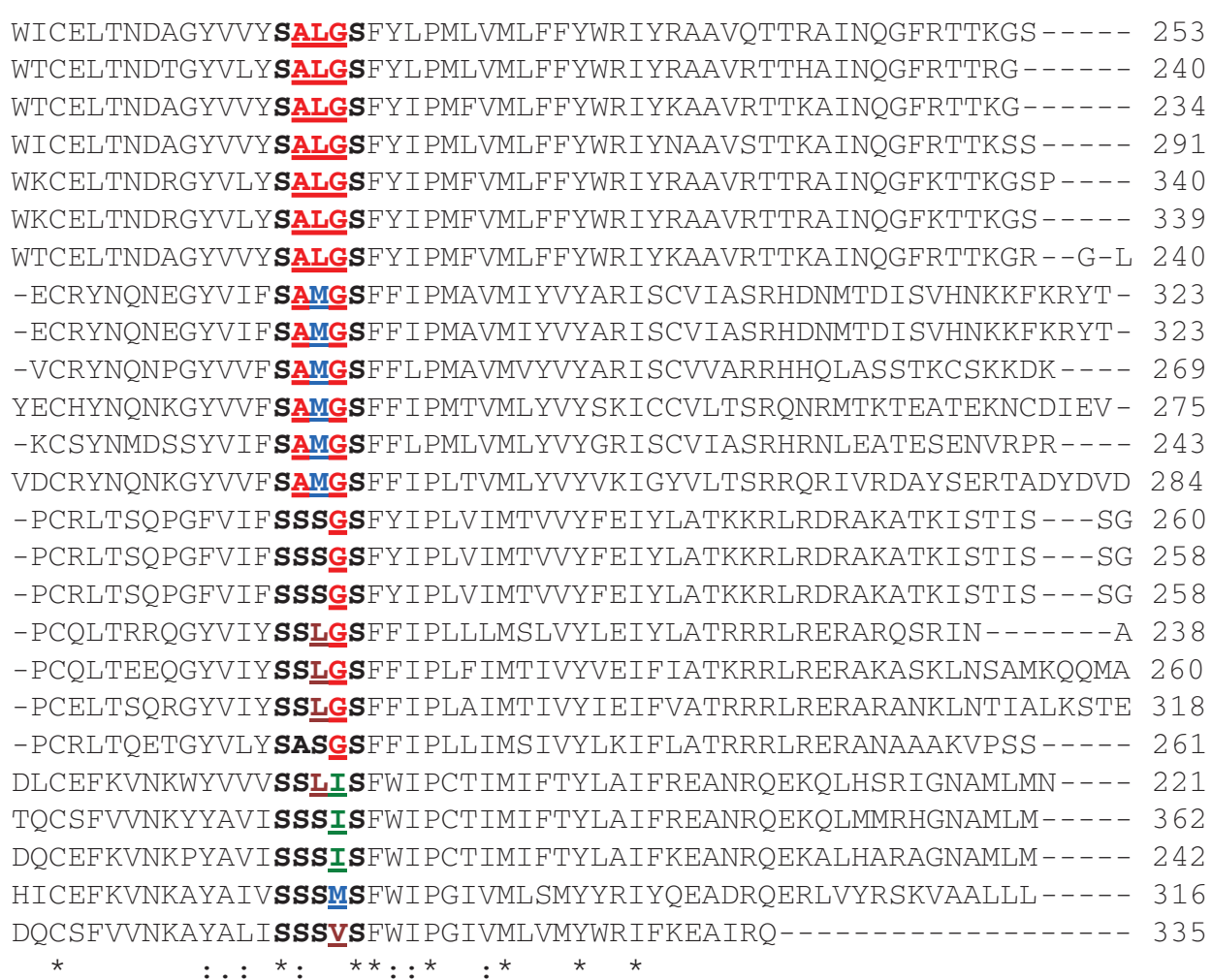

Figure 6 Amino acid sequence alignment of homologous domains present in insect octopaminergic and tyraminergic receptors.

Notes: Multiple sequence alignment of 25 insect amino acid sequences was produced by ClustalW (2.0.12). ${ }^{169} \mathrm{NCBI}$ Databank accession number of translated gene product: AmOAI, AJ547798; DmOAMB, AF065443; splice variant IA DmOAIA, AJ0076I8; splice variant IB DmOAIB, AJ0076I7; PaOAI, AY333I78; MsOA, ABI33825; SgOcto,

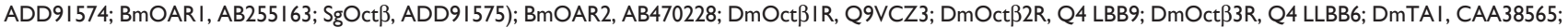
TARI, ABI62828; HvTA, CAA64864; DmTAI, X54794; AmtyrI, AJ245824; Aityr/OCT, FJ640850; BmiTA, AJ010743; Lmtyr, X69520; DmTA2, AY0346I7; Dm(CGI6766), NM_142394; Dm(CG743I), NM_I42395; BmTAR2, AB46248I; Amtyr-like, NM_00I0373I8; and Ag(GPRNNA4), XM_309588. Amino acid residues with an asterisk (*) correspond to fully conserved region. Amino acid residues with a symbol (:) correspond to amino acid residues in similar groups. Amino acid residues with a symbol (.) correspond to semiconserved substitution (similar shapes). Amino acid numbers are shown at the right. The intervening amino acids in TM5 domain between two conserved serine residues are shown in color. Two serine residues are separated by ALG in OCT $\alpha-R$; AMG in TYR2-R; G, or LG in TYRI-R; and I, M, V, or LI in OCT $\beta-R$ class. Amino acid residues: serine $(S)$, alanine $(A)$, leucine $(L)$, glycine $(G)$, methionine $(M)$, isoleucine $(I)$, and valine $(V)$.

Abbreviations: Am, Apis mellifera; Dm, Drosophila melanogaster; Pa, Periplaneta americana; Ms, Manduca sexta; Sg, Schistocerca gregaria; Bm, Bombyx mori; Hv, Heliothis virescens; Ai, Agrotis ipsilon; Bm, Bophilus microplus; Lm, Locusta migratoria; Ag, Anopheles gambiae; NCBI, National Center for Biotechnology Information; OCT, octopamine; TYR, tyramine.

protein kinase $A \cdot{ }^{117,137,138,142,143}$ The activation of Oct $\beta$-R class in response to octopamine (Figure 7) increases levels of intracellular cAMP levels but not intracellular $\mathrm{Ca}^{2+}$ levels even at concentrations up to $100 \mu \mathrm{M} .{ }^{147,149}$ Furthermore, tyramine and dopamine exert marginal effects on cAMP production. Both protein kinase $\mathrm{C}$ and protein kinase $\mathrm{A}$ influence cellular response by phosphorylating different signaling proteins, ion channels, and transcription factors.

The activation of TYR1-R class in response to tyramine, with preference to tyramine $>$ octopamine, inhibits adenylyl cyclase activity via coupling to inhibitory G proteins, inducing a decrease in intracellular cAMP levels (Figure 7). ${ }^{134,139,141,145,148}$ However, in other preparations, octopamine is more or equally as effective as tyramine in increasing intracellular $\mathrm{Ca}^{2+}$ release. ${ }^{135,136}$ These findings suggest that cloned receptors when expressed in different cell lines may be coupled with multiple effector pathways involving different G proteins. ${ }^{117}$ The TYR2-R class is specifically activated by tyramine, but not by other biogenic amines. ${ }^{150,151}$ The TYR2-R class is selectively coupled with activation of phospholipase $\mathrm{C}$ via the $\mathrm{G}_{\mathrm{q}}$ family of $\mathrm{G}$ proteins and induces intracellular $\mathrm{Ca}^{2+}$ mobilization (Figure 7), but shows no effect on intracellular cAMP concentration. ${ }^{150,151}$ Expression of the TYR2-R class predominantly in the nervous tissue of insects suggests that tyramine may act as a neurotransmitter and neuromodulator, and that these effects may be mediated by binding to the TYR2 class of receptors. ${ }^{151}$

Collectively, octopamine and tyramine exert differential effects on insect behavior through the release of second messengers ( $\mathrm{Ca}^{2+}$, cAMP, and diacylglycerol $) .{ }^{95,172-174}$ In addition to being a precursor of octopamine, tyramine is an independent transmitter. This suggestion is not only based on the labeling of tyraminergic neurons in the insect central nervous system, but also on the presence and release of tyramine from 


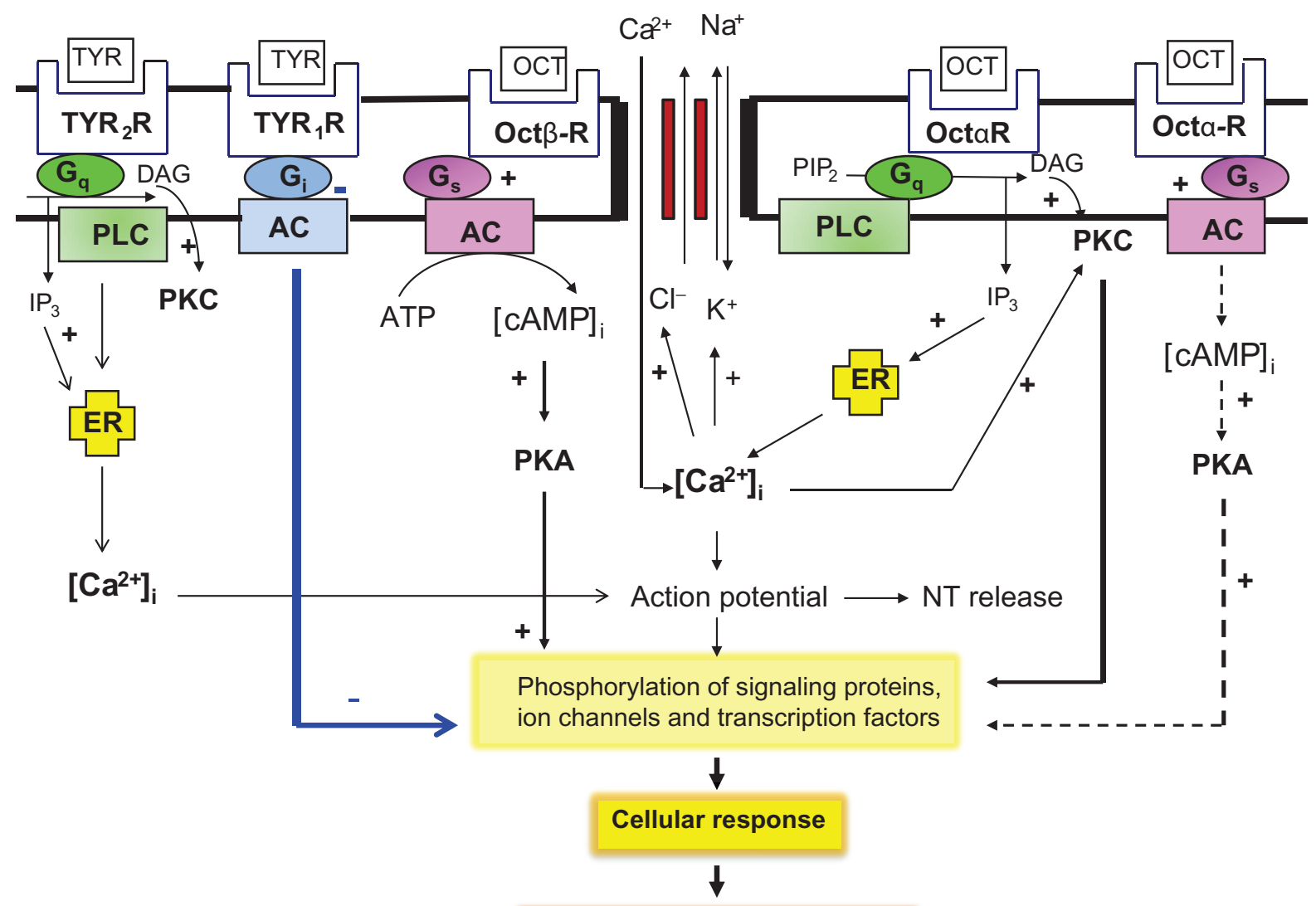

Alterations in insect behavior

Figure 7 Hypothetical overview of the octopamine and tyramine receptors and second messenger pathways involved in insect signaling.

Notes: The interaction of OCT with Oct $\alpha-R$ stimulates PLC via the $G_{q}$ protein $(G)$, inducing the generation of DAG and inositol I,4,5-trisphosphate from PIP followed by the release of intracellular calcium $\mathrm{Ca}^{2+}$ from the ER. $\mathrm{Ca}^{2+}$ and DAG then activate protein kinase $\mathrm{C}$. When cloned Oct $\alpha-\mathrm{R}$ is expressed in a cell line, it is coupled with adenylyl cyclase activation that results in relatively small increase in cAMP, which is represented by a dashed line. The interaction of OCT with Oct $\beta-R$ activates adenylyl cyclase activity via stimulatory $\mathrm{G}_{\mathrm{s}}$ protein generating $\mathrm{cAMP}$ that stimulates PKA. Both protein kinase $\mathrm{C}$ and PKA elicit a variety of cellular responses by phosphorylating different signaling proteins at serine and threonine residues, regulating their activities. The interaction of TYR with TYRI-R inhibits adenylyl cyclase activity via inhibitory $G$ protein and causes a decrease in cAMP production, whereas the interaction of OCT with TYRI-R stimulates PLC via Gq protein and is coupled with an increase in intracellular Ca ${ }^{2+}$ levels. The dual role of TYRI-R in response to TYR and OCT suggests that different agonists induce different receptor conformations, which can allow receptor coupling with different second messenger pathways, associated with selective functions in the cell. TYR specifically interacts with TYR2-R class, which is coupled with an increase in intracellular $\mathrm{Ca}^{2+}$ levels. Activation of protein kinase $\mathrm{C}$ and PKA regulate the phosphorylation of signaling proteins, ion channels, and transcription factors, regulating cellular response, and altering insect behavior.

Abbreviations: ER, endoplasmic reticulum; OCT, octopamine; PLC, phospholipase C; DAG, diacylglycerol; PKA, protein kinase A; TYR, tyramine.

neurons, removal of tyramine from the synaptic cleft by the uptake system, and the action of tyramine on specific postsynaptic receptors in the nervous tissue. Release and uptake of tyramine in insects may modulate many physiological and behavioral changes related to insect behaviors. ${ }^{151,175,176}$

\section{Conclusion}

Octopamine is widely distributed in the insect nervous system. It affects several aspects of insect physiology and behavior by acting as a neurotransmitter, a neuromodulator, and a neurohormone. The octopaminergic system of insects (invertebrates) and noradrenergic system of vertebrates are homologous. However, octopaminergic and noradrenergic systems seem to be restricted to invertebrate and vertebrate physiology, respectively. Octopamine is released by octopaminergic neurons. The binding of octopamine to octopaminergic receptors is coupled with the activation of specific $G$ proteins, which leads to transient changes in concentrations of intracellular second messengers. Further advances in molecular dissection and detailed analysis of octopaminergic signaling in insect nervous systems by using reverse molecular genetic techniques (RNA interference), DNA microarrays, and comparison of genome sequencing in more insects may aid in elucidating the molecular mechanism underlying octopamine-mediated physiological processes and behavioral changes in insects. The existence of distinct 
tyraminergic neurons and receptors in the insect nervous system indicate that tyramine can also act as an independent transmitter, at least in insects. It will be interesting to investigate the TYR2 receptor class further as soon as genome sequences become available for other insects. Greater pharmacological and functional screening of octopaminergic and tyraminergic receptors may also aid in developing specific, potent, and efficacious agonists and antagonists, which may be important when developing specific insecticides.

\section{Acknowledgments}

The reviewers are thanked for their many valuable comments and constructive criticisms of an earlier version of this manuscript.

\section{Disclosure}

The author reports no conflicts of interest in this work.

\section{References}

1. Erspamer V, Boretti G. Identification and characterization by paper chromatography of enteramine, octopamine, tyramine, histamine, and allied substances in extracts of posterior salivary glands of octopoda and in other tissue extracts of vertebrates and invertebrates. Arch Int Pharmacodyn Ther. 1951;88:296-332.

2. Axelrod J, Saavedra JM. Octopamine. Nature. 1977;265:501-504.

3. Roeder T. Octopamine in invertebrates. Prog Neurobiol. 1999; 59:533-561.

4. Orchard I. Octopamine in insects: neurotransmitter, neurohormone, and neuromodulator. Can J Zool. 1982;60:659-669.

5. Evans PD. Octopamine. In: Kerkut GA, Gilbert LI, editors. Comprehensive Insect Physiology, Biochemistry and Pharmacology, Volume 11. Oxford, UK: Pergamon Press; 1985.

6. Berry MD. Mammalian central nervous system trace amines. Pharmacologic amphetamines, physiologic neuromodulators. J Neurochem. 2004;90:257-271.

7. Borowsky B, Adham N, Jones KA, et al. Trace amines: identification of a family of mammalian G protein-coupled receptors. Proc Natl Acad Sci U S A. 2001;98:8966-8971.

8. Goosey MW, Candy DJ. The D-octopamine of the haemolymph of the locust Schistocerca gregaria and its elevation during flight. Insect Biochem. 1980;10:393-397.

9. Davenport AP, Evans PD. Stress-induced changes in the octopamine levels of insect haemolymph. Insect Biochem. 1984;14:135-143.

10. Orchard I, Loughton BG, Webb RA. Octopamine and short-term hyperlipaemia in the locust. Gen Comp Endocrinol. 1981;45:175-180.

11. Orchard I, Ramirez JM, Lange AB. A multifunctional role for octopamine in locust flight. Annu Rev Entomol. 1993;38:227-249.

12. Duch C, Pflüger HJ. DUM neurons in locust flight: a model system for amine mediated peripheral adjustments to the requirements of a central motor program. J Comp Physiol A. 1999;184:489-499.

13. Mentel T, Duch C, Stypa H, Müller U, Wegener G, Pflüger HJ. Central modulatory neurons control fuel selection in flight muscle of migratory locust. J Neurosci. 2003;23:1109-1113.

14. Woodring JP, McBride LA, Fields P. The role of octopamine in handling and exercise-induced hyperglycaemia and hyperlipaemia in Acheta domesticus. J Insect Physiol. 1989;35:613-617.

15. Fields PE, Woodring JP. Octopamine mobilization of lipids and carbohydrates in the house cricket, Acheta domesticus. J Insect Physiol. 1991;37:193-199.
16. Baines D, Downer RG. Octopamine enhances phagocytosis in cockroach hemocytes: involvement of inositol trisphosphate. Arch Insect Biochem Physiol. 1994;26:249-261.

17. Kim GS, Kim Y. Up-regulation of circulating hemocyte population in response to bacterial challenge is mediated by octopamine and 5-hydroxytryptamine via Rac1 signal in Spodoptera exigua. J Insect Physiol. 2010;56:559-566.

18. Robertson HA, Carlson AD. Octopamine presence in firefly lantern suggests a transmitter role. J Exp Zool. 1976;195:159-164.

19. Copeland J, Robertson HA. Octopamine as the transmitter at the firefly lantern-presence of an octopamine-sensitive and dopamine-sensitive adenylate cyclase. Comp Biochem Physiol C. 1982;72:125-127.

20. Lafon-Cazal M, Baehr JC. Octopaminergic control of corpora allata activity in an insect. Experentia. 1988;44:895-896.

21. Pannabecker T, Orchard I. Octopamine and cyclic AMP mediate release of adipokinetic hormone I and II from isolated locust neuroendocrine tissue. Mol Cell Endocrinol. 1986;48:153-159.

22. Evans PD, O'Shea M. An octopaminergic neurone modulates neuromuscular transmission in the locust. Nature. 1977;270:257-259.

23. Whim MD, Evans PD. Octopaminergic modulation of flight muscle in the locust. J Exp Biol. 1988;134:247-266.

24. Orchard I, Lange AB. Evidence for octopaminergic modulation of an insect visceral muscle. J Neurobiol. 1985;16:171-181.

25. Evans PD. Octopamine distribution in the insect nervous system. J Neurochem. 1978;30:1109-1113.

26. Verlinden H, Vleugels R, Marchal E, et al. The cloning, phylogenetic relationship and distribution pattern of two new putative GPCR-type octopamine receptors in the desert locust (Schistocerca gregaria). J Insect Physiol. 2010;56:868-875.

27. Sombati S, Hoyle G. Generation of specific behaviors in a locust by local release into neuropil of the natural neuromodulator octopamine. J Neurobiol. 1984;15:481-506.

28. Yellman C, Tao H, He B, Hirsh J. Conserved and sexually dimorphic behavioral responses to biogenic amines in decapitated Drosophila. Proc Natl Acad Sci U S A. 1997;94:4131-4136.

29. Barron AB, Maleszka J, Vander Meer RK, Robinson GE. Octopamine modulates honey bee dance behavior. Proc Natl Acad Sci U S A. 2007;104:1703-1707.

30. Burrell BD, Smith BH. Modulation of the honey bee (Apis mellifera) sting response by octopamine. J Insect Physiol. 1995;41:671-680.

31. Sombati S, Hoyle G. Central nervous sensitization and dishabituation of reflex action in an insect by the neuromodulator octopamine. J Neurobiol. 1984;15:455-480.

32. Bacon JP, Thompson KS, Stern M. Identified octopaminergic neurons provide an arousal mechanism in the locust brain. $J$ Neurophysiol. 1995;74:2739-2743.

33. Robinson GE, Heuser LM, LeConte Y, Lenquette F, Hollingworth RM. Neurochemicals aid bee nestmate recognition. Nature. 1999;399: 534-535.

34. Vander Meer RK, Preston CA, Hefetz A. Queen regulates biogenic amine level and nestmate recognition in workers of the fire ant, Solenopsis invicta. Naturwissenschaften. 2008;95:1155-1158.

35. Long TF, Murdock LL. Stimulation of blowfly feeding behavior by octopaminergic drugs. Proc Natl Acad Sci U S A. 1983;80: 4159-4163.

36. Cohen RW, Mahoney DA, Can HD. Possible regulation of feeding behavior in cockroach nymphs by the neurotransmitter octopamine. J Insect Behav. 2002;15:37-50.

37. Braun G, Bicker G. Habituation of an appetitive reflex in the honeybee. J Neurophysiol. 1992;67:588-598.

38. Schulz DJ, Barron AB, Robinson G. A role for octopamine in honeybee division of labor. Brain Behav Evol. 2002;60:350-359.

39. Giray T, Galindo-Cardona A, Oskay D. Octopamine influences honey bee foraging preference. J Insect Physiol. 2007;53:691-698.

40. O'Dell KM. The effect of the inactive mutation on longevity, sex, rhythm and resistance to p-cresol in Drosophila melanogaster. Heredity. 1993;70:393-399. 
41. Stern M, Thompson KSJ, Zhou P, et al. Octopaminergic neurons in the locust brain: morphological, biochemical and electrophysiological characterisation of potential modulators of the visual system. J Comp Physiol A. 1995;177:611-625.

42. Stern M. The PM1 neurons movement sensitive centrifugal visual brain neurons in the locust: anatomy, physiology, and modulation by identified octopaminergic neurons. J Comp Physiol A. 2009;195:123-137.

43. Erber J, Kloppenburg P. The modulatory effects of serotonin and octopamine in the visual system of the honey bee (Apis mellifera L): I. Behavioral analysis of the motion-sensitive antennal reflex. J Comp Physiol A. 1995;176:111-118.

44. Kloppenburg P, Erber J. The modulatory effects of serotonin and octopamine in the visual system of the honey bee (Apis mellifera L) II. Electrophysiological analysis of motion-sensitive neurons in the lobula. J Comp Physiol A. 1995;176:119-129.

45. Hammer M, Menzel R. Multiple sites of associative odor learning as revealed by local brain microinjections of octopamine in honeybees. Learn Mem. 1998;5:146-156.

46. Schwaerzel M, Monastirioti M, Scholz H, Friggi-Grelin, Birman S, Heisenberg M. Dopamine and octopaminergic differentiate between aversive and appetitive olfactory memories in Drosophila. J Neurosci. 2003;23:10495-10502.

47. Farooqui T, Robinson K, Vaessin H, Smith BH. Modulation of early olfactory processing by an octopaminergic reinforcement pathway in the honeybee. J Neurosci. 2003;23:5370-5380.

48. Mizunami M, Unoki S, Mori Y, Hirashima D, Hatano A, Matsumoto Y. Roles of octopaminergic and dopaminergic neurons in appetitive and aversive memory recall in an insect. BMC Biol. 2009;7:46.

49. Unoki S, Matsumoto Y, Mizunami M. Participation of octopaminergic reward system and dopaminergic punishment system in insect olfactory learning revealed by pharmacological study. Eur J Neurosci. 2005;22:1409-1416.

50. Danielson TJ, Boulton AA, Robertson HA. m-Octopamine, p-octopamine and phenylethanolamine in rat brain: a sensitive, specific assay and the effects of some drugs. J Neurochem. 1977;29: 1131-1135

51. Williams CM, Couch MW. Identification of ortho-octopamine and meta-octopamine in mammalian adrenal and salivary gland. Life Sci. 1978;22:2113-2220.

52. Ibrahim KE, Couch MW, William CM, Fregly MJ, Midgley JM. $m$-Octopamine: normal occurrence with $p$-octopamine in mammalian sympathetic nerves. J Neurochem. 1985;44:1862-1867.

53. Brown CM, McGrath JC, Muir AG, et al. Activities of octopamine and synephrine stereoisomers on alpha-adrenoceptors. Br J Pharmacol. 1988;93:417-429.

54. Erspamer V, Boretti G. Identification and characterization, by paper chromatography, of enteramine, octopamine, tyramine, histamine and allied substances in extracts of posterior salivary glands of octopoda and in other tissue extracts of vertebrates and invertebrates. Arch Int Pharmacodyn Ther. 1951;88:296-332.

55. Starratt AN, Bodnaryk RB. Stereoisomeric identity of octopamine in the central nervous system of invertebrates. Insect Biochem. 1981; 11:645-648

56. Mercer AR, Menzel R. The effects of biogenic amines on conditioned and unconditioned responses to olfactory stimuli in the honeybee Apis mellifera. J Comp Physiol A. 1982;145:363-368.

57. Harmar AJ, Horn AS. Octopamine-sensitive adenylate cyclase in cockroach brain: effects of agonists, antagonists, and guanylyl nucleotides. Mol Pharmacol. 1976;13:512-520.

58. Ramirez JM, Orchard I. Octopaminergic modulation of the forewing stretch receptor in the locust Locusta migratoria. J Exp Biol. 1990;149:255-279.

59. Roeder T. Pharmacology of the octopamine receptor from locust central nervous tissue (OAR3). Br J Pharmacol. 1995;114:210-216.

60. Livingstone MS, Tempel BL. Genetic dissection of monamine neurotransmitter synthesis in Drosophila. Nature. 1983;303:67-70.
61. Monastirioti M, Linn CE, White K. Characterization of Drosophila tyramine $\beta$-hydroxylase gene and isolation of mutant flies lacking octopamine. J Neurosci. 1996;16:3900-3911.

62. Lehman HK, Murgiuc CM, Hildebrand JG. Characterization and developmental regulation of tyramine $\beta$-hydroxylase in the CNS of a moth Manduca sexta. Insect Biochem Mol Biol. 2000;30: 377-386.

63. Cole SH, Carney GE, McClung CA, Willard SS, Taylor BJ, Hirsh J. Two functional but noncomplementing Drosophila tyrosine decarboxylase genes: distinct roles for neural tyramine and octopamine in female fertility. J Biol Chem. 2005;280:14948-14955.

64. Monastirioti M. Distinct octopamine cell population residing in the CNS abdominal ganglion controls ovulation in Drosophila melanogaster. Dev Biol. 2003;264:38-49.

65. Zhou C, Rao Y, Rao Y. A subset of octopaminergic neurons are important for Drosophila aggression. Nat Neurosci. 2008;11:1059-1067.

66. Blumenthal EM. Regulation of chloride permeability by endogenously produced tyramine in the Drosophila Malpighian tubule. Am J Physiol Cell Physiol. 2003;284:C718-C728.

67. Vaughan PF, Neuhoff V. The metabolism of tyrosine, tyramine, and L-3,4-dihydroxyphenylalanine by cerebral and thoracic ganglia of the locust, Schistocerca gregaria. Brain Res. 1976;117:175-180.

68. Hoyle G, Barker DL. Synthesis of octopamine by insect dorsal median unpaired neurons. J Exp Zool. 1976;193:433-439.

69. Evans PD. Biogenic amines in the insect nervous system. Adv Insect Physiol. 1980;15:317-473.

70. Mir AK, Vaughan PFT. The biosynthesis of dopamine and octopamine by Schistocerca gregaria nervous tissues. Proc Eur Soc Neurochem. 1978; $1: 533$.

71. Macfarlane RG, Midgley JM, Watson DG, Evans PD. The analysis of biogenic amines in the thoracic nervous system of the locust (Schistocerca gragaria) by gas-chromatography negative ion chemical ionization mass spectroscopy (GC-NICIMS). Insect Biochem. 1990;20:305-311.

72. Horner M. Cytoarchitecture of histamine-, dopamine-, serotonin- and octopamine-containing neurons in the cricket ventral nerve cord. Microsc Res Tech. 1999;44:137-165.

73. Owen MD, Bouqillon AI. The synthesis of L-dihydroxyphenylalanine (L-dopa) in the cerebral ganglia of the cockroach, Periplaneta Americana L. Insect Biochem Mol Biol. 1992;22:193-198.

74. Murdock LL, Wirtz RA, Kohler G. 3,4-Dihydroxyphenylalanine (dopa) decarboxylase activity in the arthropod nervous system. Biochem J. 1973;132:681-688.

75. Walker RJ, Kerkut GA. The first family (adrenaline, noradrenaline, dopamine, octopamine, tyramine, phenylethanolamine and phenylethylamine). Comp Biochem Physiol C. 1978;61:261-266.

76. David JC, Coulon JF, Lafon-Cazal M, Vinson D. Can L-DOPA be a precursor of m-octopamine in the cephalic ganglion of the locust, Locust migratoria L? Experientia. 1981;37:804-805.

77. Coulon JF, Lafon-Cazal M, David JC. In vitro occurrence of m-octopamine in the cultured cephalic ganglion of Locusta migratoria L, after L-DOPA administration. Comp Biochem Physiol C. 1984;78: 77-80.

78. Goosey MW, Candy DJ. The release and removal of octopamine by tissues of the locust Schistocerca gregaria. Insect Biochem. 1982;12:681-685

79. Morton DB, Evans PD. Octopamine release from an identified neuron in the locust. $J$ Exp Biol. 1984;113:269-287.

80. Orchard I, Lange AB. The release of octopamine and proctolin from an insect visceral muscle: effects of high-potassium saline and neural stimulation. Brain Res. 1987;413:251-258.

81. Orchard I, Lange AB. Cockroach oviducts: the presence and release of octopamine and proctolin. J Insect Physiol. 1987;33:265-268.

82. Consoulas C, Johnston RM, Pflüger HJ, Levine RB. Peripheral distribution of presynaptic release sites of abdominal motor and modulatory neurons in Manduca sexta larvae. J Comp Neurol. 1999;410:4-19. 
83. Roeder T, Gewecke M. Octopamine uptake systems in thoracic ganglia and leg muscles of Locusta migratoria. Comp Biochem Physiol. 1984;94:143-147.

84. Scavone C, McKee M, Nathanson JA. Monoamine uptake in insect synaptosomal preparations. Insect Biochem Mol Biol. 1994; 24:589-597.

85. Malutan T, McLean H, Caveney S, Donly C. A high-affinity octopamine transporter cloned from the central nervous system of cabbage looper Trichoplusia ni. Insect Biochem Mol Biol. 2002;32: 343-357.

86. Donly BC, Caveney S. A transporter for phenolamine uptake in the arthropod CNS. Arch Insect Biochem Physiol. 2005;59:172-183.

87. Gründemann D, Gorboulev V, Gambaryan S, Veyhl M, Koepsell H. Drug excretion mediated by a new prototype of polyspecific transporter Nature. 1994;372:549-552.

88. Sloan JL, Mager S. Cloning and functional expression of a human $\mathrm{Na}(+)$ and $\mathrm{Cl}(-)$-dependent neutral and cationic amino acid transporter B (0+). J Biol Chem. 1999;274:23740-23745.

89. Nathanson JA, Hunnicutt EJ, Kantham L, Scavone C. Cocaine as a naturally occurring insecticide. Proc Natl Acad Sci U S A. 1993;90: 9645-9648.

90. Hayashi S, Murdock LL, Florey E. Octopamine metabolism in invertebrates (Locusta, Astacus, Helix): evidence for N-acetylation in arthropod tissues. Comp Biochem Physiol C. 1977;58C:183-191.

91. Downer RG, Martin RJ. Analysis of monoamines and their metabolites by high performance liquid chromatography with coulometric electrochemical detection. Life Sci. 1987;41:833-836.

92. Martin RJ, Downer RG. Microassay for N-acetyltransferase activity using high-performance liquid chromatography with electrochemical detection. J Chromatogr. 1989;487:287-293.

93. Sloley BD. Metabolism of monoamines in invertebrates: the relative importance of monoamine oxidase in different phyla. Neurotoxicology 2004;25:175-183.

94. Roeder T. Tyramine and octopamine: ruling behavior and metabolism. Annu Rev Entomol. 2005;50:447-477.

95. Wierenga JM, Hollingworth RM. Octopamine uptake and metabolism in the insect nervous system. J Neurochem. 1990;54:479-489.

96. Paxon TL, Powell PR, Lee HG, Han KA, Ewing AG. Microcolumn separation of amine metabolites in the fruit fly. Anal Chem. 2005;77: 5349-5355.

97. Kempton LRC, Isaac RE, Pillmoor JB, Willis RJ. Octapamine $\mathrm{N}$-acetyltransferase activity from the cattle tick, Boophilus microplus. Insect Biocem Mol Biol. 1992;22:777-783.

98. Roeder T, Seifert M, Kahler C, Gewecke M. Tyramine and octopamine: antagonistic modulators of behavior and metabolism. Arch Insect Biochem Physiol. 2003;54:1-13.

99. Richardt A, Kemme T, Wagner S, Schwarzer D, Marahiel MA, Hovemann BT. Ebony, a novel nonribosomal peptide synthetase for beta-alanine conjugation with biogenic amines in Drosophila. J Biol Chem. 2003;278:41160-41166.

100. Blenau W, Baumann A. Molecular characterization of the ebony gene from the American cockroach, Periplaneta americana. Arch Insect Biochem Physiol. 2005;59:184-195.

101. Battelle BA, Edwards SC, Kass L, Maresch HM, Pierce SK, Wishart AC. Identification and function of octopamine and tyramine conjugates in the Limulus visual system. J Neurochem. 1988;51: 1240-1251.

102. Kennedy MB. Products of biogenic amine metabolism in the lobster: sulfate conjugates. J Neurochem. 1978;30:315-320.

103. McCaman MW, Stetzler J, Clark B. Synthesis of gammaglutamyldopamine and other peptidoamines in the nervous system of Aplysia californica. J Neurochem. 1985;45:1828-1835.

104. Stuart JN, Zhang X, Jakubowski JA, Romanova EV, Sweedler JV. Serotonin catabolism depends upon location of release: characterization of sulfated and $\gamma$-glutamylated serotonin metabolites in Aplysia californica. J Neurochem. 2003;84:1358-1366.
105. Kreissl S, Eichmuller S, Bicker G, Rapus J, Eckert M. Octopamine-like immunoreactivity in the brain and subesophageal ganglion of the honeybee. J Comp Neurol. 1994;348:583-595.

106. Sinakevitch I, Niwa M, Strausfeld NJ. Octopamine-like immunoreactivity in the honey bee and cockroach: comparable organization in the brain and subesophageal ganglion. J Comp Neurol. 2005;488:233-254.

107. Sinakevitch I, Strausfeld NJ. Comparison of octopamine-like immunoreactivity in the brains of the fruit fly and blow fly. J Comp Neurol. 2006;494:460-475.

108. Monastirioti M. Biogenic amine systems in the fruit fly Drosophila melanogaster. Microsc Res Tech. 1999;45:106-121.

109. Stevenson PA, Spörhase-Eichmann U. Localization of octopaminergic neurones in insects. Comp Biochem Physiol A Physiol. 1995; 110:203-215.

110. Eckert M, Rapus J, Nürnberger A, Penzlin H. The octopaminergic system within the ventral nerve cord of the American cockroach. Acta Biol Hung. 1992;43:201-211.

111. Dacks AM, Christensen TA, Agricola HJ, Wollweber L, Hildebrand JG. Octopamine-immunoreactive neurons in the brain and subesophageal ganglion of the hawkmoth Manduca sexta. J Comp Neurol. 2005;488:255-268

112. Konings PNM, Vullings HGB, Geffard M, Buijs RM, Diederen JHB, Jansen WF. Immunohistochemical demonstration of octopamineimmunoreactive cells in the nervous system of Locusta migratoria and Schistocerca gregaria. Cell Tissue Res. 1988;251:371-379.

113. Hoyle G. Evidence that insect dorsal unpaired median (DUM) neurons are octopaminergic. J Exp Zool. 1975;193:425-431.

114. Hoyle G. The dorsal, unpaired, median neurons of the locust metathoracic ganglion. $J$ Neurobiol. 1978;9:59-79.

115. Heidel E, Pflüger HJ. Ion currents and spiking properties of identified subtypes of locust octopaminergic dorsal unpaired median neurons. Eur J Neurosci. 2006;23(5):1189-1206.

116. Bräunig P, Pflüger HJ. The unpaired median neurons of insects. $A d v$ Insect Physiol. 2001;28:185-266.

117. Farooqui T. Octopamine-mediated neuromodulation of insect senses. Neurochem Res. 2007;32:1511-1529.

118. Bräunig P. Suboesophageal DUM neurones innervate the principal neuropiles of the locust brain. Philos Trans R Soc Lond. B 1991;322:221-240.

119. Field LH, Duch C, Pflüger HJ. Responses of efferent octopaminergic thoracic unpaired median neurons in the locust to visual and mechanosensory signals. J Insect Physiol. 2008;54:240-254.

120. Adamo SA, Linn CE, Hoy RR. The role of neurohormonal octopamine during 'fight or flight' behavior in the field cricket Gryllus bimaculatus. J Exp Biol. 1995;198:691-1700.

121. Pflüger HJ, Duch C. Dynamic neural control of insect muscle metabolism related to motor behavior. Physiology. 2011;26:293-303.

122. Verlinden H, Vleugels R, Marchal E, et al. The role of octopamine in locusts and other arthropods. J Insect Physiol. 2010;56:854-867.

123. Bräunig P, Burrows M, Morris OT. Properties of descending dorsal unpaired median (DUM) neurons of the locust suboesophageal ganglion. Acta Biol Hung. 2004;55(1-4):13-19.

124. Schröter U, Malun D, Menzel R. Innervation pattern of suboesophageal ventral unpaired median neurones in the honeybee brain. Cell Tissue Res. 2007;327:647-667.

125. Evans PD. Multiple receptor types for octopamine in the locust. J Physiol. 1981;318:99-122.

126. Evans PD. Molecular studies on insect octopamine receptors. In: Pichon Y, editor. Comprehensive Molecular Neurobiology. Basel, Switzerland: Birkhauser-Verlag; 1993.

127. Evans PD, Robb S. Octopamine receptor subtypes and their modes of action. Neurochem Res. 1993;18:869-874.

128. Roeder T. A new octopamine receptor class in locust nervous tissue, the octopamine3 (OA3) receptor. Life Sci. 1992;50:21-28.

129. Roeder T. Pharmacology of octopamine receptor from locust central nervous tissue (OAR3). Br J Pharmacol. 1995;114:210-216. 
130. Roeder T, Nathanson JA. Characterization of insect neuronal octopamine receptors (OA3 receptors). Neurochem Res. 1993;18: 921-925.

131. Arakawa S, Gocayne JD, McCombie WR, et al. Cloning, localization, and permanent expression of a Drosophila octopamine receptor. Neuron. 1990;4:343-354.

132. Saudou F, Amlaiky N, Plassat JL, et al. Cloning and characterization of a Drosophila tyramine receptor. EMBO J. 1990;9:3611-3617.

133. Vanden Broeck J, Vulsteke V, Huybrechts R, et al. Characterization of a cloned locust tyramine receptor cDNA by functional expression in permanently transformed Drosophila S2 cells. J Neurochem. 1995;64:2387-2395.

134. von Nicksch-Rosenegk E, Krieger J, Kubick S, et al. Cloning of biogenic amine receptors from moths (Bombyx mori and Heliothis virescens). Insect Biochem Mol Biol. 1996;26:817-827.

135. Robb S, Cheek TR, Hannan FL, Hall LM, Midgley JM, Evans PD. Agonist-specific coupling of a cloned Drosophila octopamine/ tyramine receptor to multiple second messenger systems. EMBO J. 1994;13:1325-1330.

136. Reale V, Hannan F, Midgley JM. The expression of a cloned Drosophila octopamine/tyramine receptor in Xenopus oocytes. Brain Res. 1997;769:309-320.

137. Han KA, Millar NS, Davis RL. A novel octopamine receptor with preferential expression in Drosophilla mushroom bodies. J Neurosci. 1998;18:3650-3658.

138. Grohmann L, Blenau W, Erber J, Ebert PR, Strünker T, Baumann A. Molecular and functional characterization of an octopamine receptor from honeybee (Apis mellifera) brain. J Neurochem. 2003;86: 725-735.

139. Poels J, Suner MM, Needham M, et al. Functional expression of a locust tyramine receptor in murine erythroleukemia cells. Insect $\mathrm{Mol}$ Biol. 2001;10:541-548.

140. Ohta H, Utsumi T, Ozoe Y. B96Bom encodes a Bombyx mori tyramine receptor negatively coupled to adenylate cyclase. Insect $\mathrm{Mol}$ Biol. 2003;12:217-223.

141. Duportets L, Barrozo RB, Bozzolan F, et al. Cloning of an octopamine/ tyramine receptor and plasticity of its expression as a function of adult sexual maturation in the male moth Agrotis ipsilon. Insect Mol Biol. 2010;19:489-499.

142. Bischof LJ, Enan EE. Cloning, expression and functional analysis of an octopamine receptor from Periplaneta americana. Insect Biochem Mol Biol. 2004;34:511-521.

143. Balfanz S, Strünker T, Frings S, Baumann A. A family of octopamine receptors that specifically induce cyclic AMP production or $\mathrm{Ca}^{2+}$ release in Drosophila melanogaster. J Neurochem. 2005;93:440-451.

144. Maqueira B, Chatwin H, Evans PD. Identification and characterization of a novel family of Drosophila $\beta$-adrenergic-like octopamine G-protein coupled receptors. J Neurochem. 2005;94:547-560.

145. Ohtani A, Arai Y, Ozoe F, et al. Molecular cloning and heterologous expression of an alpha adrenergic-like octopamine receptor from the silkworm Bombyx mori. Insect Mol Biol. 2006;15:763-772.

146. Dacks AM, Dacks JB, Christensen TA, Nighorn AJ. The cloning of one putative octopamine receptor and two putative serotonin receptors from the tobacco hawkmoth, Manduca sexta. Insect Biochem Mol Biol. 2006;36:741-747

147. Baxter GD, Barker SC. Isolation of a cDNA for an octopamine-like, G-protein coupled receptor from the cattle tick, Boophilus microplus. Insect Biochem Mol Biol. 1999;29:461-467.

148. Blenau W, Balfanz S, Baumann A. Amtyr1: characterization of a gene from honeybee (Apis mellifera) brain encoding a functional tyramine receptor. J Neurochem. 2000;74:900-908

149. Evans PD, Maqueira B. Insect octopamine receptors: a new classification scheme based on studies of cloned Drosophila G-protein coupled receptors. Invert Neurosci. 2005;5:111-118.

150. Cazzamali G, Klaerke DA, Grimmelikhuijzen CJP. A new family of insect tyramine receptors. Biochem Biophys Res Commun. 2005;338:1189-1196.
151. Huang J, Ohta H, Inoue $N$, et al. Molecular cloning and pharmacological characterization of a Bombyx mori tyramine receptor selectively coupled to intracellular calcium mobilization. Insect Biochem $\mathrm{Mol}$ Biol. 2009;39:842-849.

152. Chen X, Ohta H, Ozoe F, Miyazawa K. Huang J, Ozoe Y. Functional and pharmacological characterization of a beta-adrenergic-like octopamine receptor from the silkworm Bombyx mori. Insect Biocem Mol Biol. 2010;40:476-486.

153. Dereeper A, Audic S, Claverie JM, Blanc G. Blast-Explorer helps you building datasets for phylogenetic analysis. BMC Evol Biol. 2010;10:8.

154. Edgar RC. Multiple sequence alignment with high accuracy and high throughput. Nucleic Acids Res. 2004;32:1792-1797.

155. Anisimova M, Gascuel O. Approximate likelihood ratio test for branchs: a fast, accurate and powerful alternative. Syst Biol. 2006; 55:539-552.

156. Strader CD, Fong TM, Graziano MP, Tota MR. The family of G-protein coupled receptors. FASEB J. 1995;9:745-754.

157. Valdenaire O, Vernier P. G protein coupled receptors as modules of interacting proteins: a family meeting. Prog Drug Res. 1997;49:173-218.

158. Blenau W, Baumann A. Molecular and pharmacological properties of insect biogenic amine receptors: lessons from Drosophila melanogaster and Apis mellifera. Arch Insect Biochem Physiol. 2001;48:13-38.

159. Park Y, Adams ME. Insect G protein-coupled receptors: Recent discoveries and implications. In: Gilbert LI, Iatrou K, Gill SS, editors. Comprehensive Molecular Insect Science. Volume 5. Oxford, UK: Elsevier; 2005.

160. Farooqui T. Octopamine-mediated neuronal plasticity in honeybees: implications for olfactory dysfunction in humans. Neuroscientist. 2007;13:304-322.

161. Probst WC, Snyder LA, Schuster DI, Brosius J, Sealfon SC. Sequence alignment of the G-protein coupled receptor superfamily. DNA Cell Biol. 1992;11:1-20.

162. Huang J, Hamasaki T, Ozoe F, et al. Identification of critical structural determinants responsible for octopamine binding to the alphaadrenergic-like Bombyx mori octopamine receptor. Biochemistry. 2007;46:5896-5903.

163. Huang J, Hamasaki T, Ozoe F, Ozoe Y. Single amino acid of an octopamine receptor as a molecular switch for distinct $\mathrm{G}$ protein couplings. Biochem Biophys Res Commun. 2008;371:610-614.

164. Farooqui T, Vaessin H, Smith BH. Octopamine receptors in the honeybee (Apis mellifera) brain and their disruption by RNA-mediated interference. J Insect Physiol. 2004;50:701-713.

165. Smotrys JE, Linder ME. Palmitoylation of intracellular signaling proteins: regulation and function. Annu Rev Biochem. 2004;73: 559-587.

166. Goddard AD, Watts A. Regulation of $\mathrm{G}$ protein-coupled receptors by palmitoylation and cholesterol. BMC Biol. 2010;10:27.

167. Chini B, Parenti M. G-protein-coupled receptors, cholesterol and palmitoylation: facts about fats. J Mol Endocrinol. 2009;42:371-379.

168. Rudling JE, Kennedy K, Evans PD. The effect of site-directed mutagenesis of two transmembrane serine residues on agonist-specific coupling of a cloned human $\alpha_{2 \mathrm{~A}}$-adrenoceptor to adenylyl cyclase. Br J Pharmacol. 1999;127:877-886.

169. Sato T, Kobayashi H, Nagao T, Kurose H. Ser203 as well as Ser204 and Ser207 in fifth transmembrane domain of the human $\beta_{2}$-adrenoceptor contributes to agonist binding and receptor activation. Br J Pharmacol. 1999;128:272-274.

170. Rudling JE, Richardson J, Evans PD. A comparison of agonist-specific coupling of cloned alpha (2)-adrenoceptor subtypes. Br J Pharmacol. 2000;131:933-941.

171. Thompson JD, Higgins DG, Gibson TJ. CLUSTALW: improving the sensitivity of the progressive multiple sequence alignment through sequence weighting, position-specific gap penalties and weight matrix choice. Nucleic Acids Res. 1994;22:4673-4680. 
172. Vierk R, Pflueger HJ, Duch C. Differential effects of octopamine and tyramine on the central pattern generator for Manduca flight. J Comp Physiol A Neuroethol Sens Neural Behav Physiol. 2009; 195:265-277.

173. Saraswati S, Fox LE, Soll DR, Wu CF. Tyramine and octopamine have opposite effects on the locomotion of Drosophila larvae. J Neurobiol. 2004;5:425-441.

174. Hardie SL, Zhang JX, Hirsh J. Trace amines differentially regulate adult locomotor activity, cocaine sensitivity, and female fertility in Drosophila melanogaster. Dev Neurobiol. 2007;67:1396-1405.
175. Lange AB. Tyramine: from octopamine precursor to neuroactive chemical in insects. Gen Comp Endocrinol. 2009;162:18-26.

176. Kononenko NL, Wolfenberg H, Pflüger HJ. Tyramine as an independent transmitter and a precursor of octopamine in the locust central nervous system: an immunocytochemical study. J Comp Neurol. 2009;512:433-452.

Open Access Insect Physiology

\section{Publish your work in this journal}

Open Access Insect Physiology is an international, peer-reviewed, open access journal publishing original research, reports, reviews and commentaries on all areas of insect physiology. The manuscript management system is completely online and includes a very quick and fair peer-review system, which is all easy to use.

\section{Dovepress}

Visit http://www.dovepress.com/testimonials.php to read real quotes from published authors. 